\title{
Innovation practices in emerging economies: Do university partnerships matter?
}

\author{
Maribel Guerrero ${ }^{1}$ (D) David Urbano ${ }^{2} \cdot$ Fernando Herrera $^{3}$
}

Published online: 20 April 2017

(C) The Author(s) 2017. This article is an open access publication

\begin{abstract}
Enterprises' resources and capabilities determine their ability to achieve competitive advantage. In this regard, the key innovation challenges that enterprises face are liabilities associated with their age and size, and the entry barriers imposed on them. In this line, a growing number of enterprises are starting to implement innovation practices in which they employ both internal/external flows of knowledge in order to explore/exploit innovation in collaboration with commercial or scientific agents. Within this context, universities play a significant role providing fertile knowledge-intensive environments to support the exploration and exploitation of innovative and entrepreneurial ideas, especially in emerging economies, where governments have created subsidies to promote enterprise innovation through compulsory university partnerships. Based on these ideas, the purpose of this exploratory research is to provide a better understanding about the role of universities on enterprises' innovation practices in emerging economies. More concretely, in the context of Mexico, we explored the enterprises' motivations to collaborate with universities in terms of innovation purposes (exploration and exploitation) or alternatives to access to public funds (compulsory requirement of being involved in a university partnership). Using a sample of 10,167 Mexican enterprises in the 2012 Research and Technological Development Survey collected by the Mexican National Institute of Statistics and Geography, we tested a multinomial regression model. Our results provide insights
\end{abstract}

Maribel Guerrero

maribel.guerrero@northumbria.ac.uk

David Urbano

david.urbano@uab.cat

Fernando Herrera

fernando.herrera@itesm.mx

1 Newcastle Business School, Northumbria University, Newcastle upon Tyne NE1 8ST, UK

2 Department of Business, Universitat Autònoma de Barcelona, Edifici B, Campus UAB, 08913 Bellaterra, Barcelona, Spain

3 Engineering and Science Department, Campus León, Tecnológico de Monterrey, Av. Eugenio Garza Sada S/N. Colonia Cerro Gordo, C.P. 37190 León, Guanajuato, Mexico 
about the relevant role of universities inside enterprises' exploratory innovation practices, as well as, in the access of $R \& D$ research subsidies.

Keywords Innovation process · Resources and capabilities · Dynamic capabilities $\cdot$ Enterprise \& university partnerships $\cdot$ Entrepreneurial universities $\cdot$ Emerging economies $\cdot$ Mexico

JEL Classification M21 $\cdot \mathrm{I} 23 \cdot \mathrm{O} 31 \cdot \mathrm{O} 38$

\section{Introduction}

The literature has traditionally explained that innovation practices in enterprises are motivated by potential outcomes in terms of innovation performance (Hagedoorn 1993), technological evolution (Rosenkopf and Nerkar 2001), product introduction (Laursen and Salter 2006), and the types of collaborations they engage in (Rothwell and Dodgson 1991; Tsai and Wang 2009). However, in order to identify the key motivational conditions of innovation practices, it is essential to understand the enterprises' structures and strategies. According to the resource-based view (RBV), the enterprises' resources and capabilities determine their ability to achieve competitive advantage (Amit and Schoemaker 1993; Barney 1991; Grant 1991; Penrose 1959). In this regard, over the past quarter-century, a large body of theoretical and empirical work has helped to shape our understanding of how enterprises' resources and capabilities lead to differences in survival and performance (Wernerfelt 1984; Amit and Schoemaker 1993; McGrath et al. 1995; Miller and Shamsie 1996; Gruber et al. 2008). The dynamic capabilities approach helps to explain how enterprises tend to integrate, build, and reconfigure internal/external resources/competences in response to rapidly-changing environments (Teece et al. 1997), and how they implement certain routines (Zollo and Winter 2002), processes or rules depending on the market dynamics (Eisenhardt and Martin 2000), thereby developing a capacity to purposefully create, extend, or modify their resource base (Helfat et al. 2007; Helfat and Peteraf 2003). Although not explicitly addressed in the prior literature, it seems that organizations can have several different kinds of dynamic capabilities, such as idea generation capabilities, market disruption capabilities, new product development capabilities, marketing capabilities and new process development capabilities (Easterby-Smith et al. 2009 , p. 4). Therefore, enterprises may reallocate their resources to create capabilities (Narayanan et al. 2009) designed to shape or seize opportunities, or maintain competitiveness (Teece 2007, p. 1319); for example, functional capabilities linked to innovation practices. In this respect, Boyd (1991) argues that enterprises investigate collaborations aimed at exploiting/exploring opportunities in an existing/new market based on their internal strengths/weaknesses and external opportunities/threats in developed economies. According to Colombo and Delmastro (2002) and Gruber and Henkel (2006), the key innovation challenges that enterprises face are liabilities associated with their age and size, and the entry barriers imposed on them. Enterprises are confronted with substantial liabilities due to a lack of organizational structure (e.g. the distribution of roles, tasks, and capabilities among members), which leads to inefficiency, disadvantages, and higher failure rates as compared to established ventures (Hannan and Freeman 1984; Romanelli 1989) or a lack of financial resources limits the ability of small new enterprises to withstand unfavorable business conditions and makes them vulnerable to even minor 
inefficiencies (Acs and Audretsch 1991; Carson 1985;). On the other hand, the existence of entry barriers (e.g. cost advantages of incumbent ventures, product differentiation of incumbent ventures, capital requirements, customer switching costs, access to distribution channels, and government policies) decreases the likelihood, scope, and speed with which enterprises can enter a market and establish themselves as competitors against incumbents (Porter 1979, 1980). Those barriers to market entry pose a major challenge for enterprises in terms of performance (Capon et al. 1990) and innovation practices (Damanpour 1991; Rosenbusch et al. 2011).

In line with these arguments, a growing number of enterprises are starting to implement innovation practices in which they employ both internal/external flows of knowledge in order to explore/exploit innovation in collaboration with commercial or scientific agents (Yamin and Otto 2004; van de Vrande et al. 2009). Within this context, universities play a significant role in entrepreneurial innovation processes (Audretsch 2014; Shane 2003), by providing fertile knowledge-intensive environments to support the exploration and exploitation of innovative and entrepreneurial ideas (Grimaldi et al. 2011; Guerrero et al. 2014a, b, 2015; Guerrero and Urbano 2012; Kirby et al. 2011; O'Shea et al. 2005, 2007; Rothaermel et al. 2007; Urbano and Guerrero 2013; Wright et al. 2007), especially in emerging economies, where governments have created subsidies to promote enterprise innovation through compulsory university partnerships as a strategy to stimulate regional economic development and the transition from an efficiency economy to an innovation economy (Cohen et al. 2002). As a consequence, in both developed and developing economies, public research has been oriented to industry's needs and public resources have been conditioned by the new rules of the game whereby universities contribute to social and economic development (Grimaldi et al. 2011). In this context, universities attempt to transform their business models by taking into account the needs, priorities and capabilities of all stakeholders (Miller et al. 2014). However, in emerging economies, university transformation is slow because there is not a strong base to build upon and obtain highquality research outcomes, while enterprises interested in partnerships usually face challenges in terms of communication, expectations, and agreements. To date, limited attention has been given to the importance of enterprise-university partnership in transforming emerging economies into innovative economies in which the generation, transfer and commercialization of knowledge becomes a pillar of economic development. The main reason for this is the lack of databases or other sources of information, as well as the emerging stage of applied and non-applied research designed to generate economic value. If we compare developed economies and transitional economies, we observed some similarities and differences. For instance, improving the performance of the labor market, the productive potential of the economy, and social cohesion are common objectives in most developed and transitional economies (Quintini and Martin 2014, p. 9). Despite these common goals, previous studies (Souto-Otero and Whitworth 2016) have highlighted how the challenges faced by both types of economies are somewhat different in terms of demographic trends; labor market; educational enrolment; institutions supporting; social attitudes; and the quality versus the quantity of innovations. In this regard, one example is Mexico, a relevant country in the global context because of the size of its economy and its leadership position in Latin America (World Economic Forum 2013, 2014), and where universities currently play a major role in the development of an innovation ecosystem, the transition to the Knowledge Economy (Guerrero and Urbano 2012). As a consequence, the university business model is also in a state of transition, whereby knowledge transfer and innovation processes are evolving into primarily innovation processes (Chesbrough 2003; Miller et al. 2014), with multiple stakeholders trying to exert an influence on the process 
(Alsos et al. 2011). Based on these ideas, the purpose of this exploratory research is to provide a better understanding about the role of universities on enterprises' innovation practices in emerging economies. More concretely, in the context of Mexico, we explored the enterprises' motivations to collaborate with universities in terms of innovation purposes (exploration and exploitation) or alternatives to access to public funds (compulsory requirement of being involved in a university partnership). In this sense, using a sample of 10,167 Mexican enterprises in the 2012 Research and Technological Development Survey (ESIDET) collected by the Mexican National Institute of Statistics and Geography (INEGI), we propose a multinomial regression model to study the role of universities in enterprises' innovation practices. This study tries to contributes to the debate on innovation by providing insights about the role of universities in enterprises' exploitative and exploratory innovation practices, as well as, contributing to the debate around the strategies implemented by governments to stimulate regional economic development and the transition from an efficiency economy to an innovation economy via subsidies to promote enterprise innovation through compulsory university partnerships.

The paper is organized as follows: Sect. 2 presents a review of the literature on universities' involvement in enterprises' innovation practices, and the proposed conceptual model. Section 3 provides some elements to contextualize the study in the light of Mexican Innovation Ecosystem. Section 4 describes the methodological design, including data collection and statistical analysis. Section 5 presents the results obtained and discusses them in the light of previous studies. Finally, Sect. 6 contains the concluding remarks, including the limitations and implications of our study, and avenues for further research.

\section{Highlighting universities' partnerships in enterprises' innovation practices}

The exploitation practices involve the refinement and extension of existing knowledge while exploration practices refer a learning process or acquisition of new external knowledge (Alcalde and Guerrero 2016). The selection of innovation practices depends on the ability to exploit/explore innovative capabilities that in some cases involves creating markets for intellectual property that was owned by the enterprises but not exploited by them (Arora and Fosfuri 2003; Kim and Kogut 1996). Following this assumption, enterprises collaborate in order to facilitate direct and systematic use of external resources (Becker and Dietz 2004). However, each type of collaboration involves different transaction costs due to information asymmetry, asset specificity, opportunistic behavior, and uncertainty regarding the appropriation of the income produced (Nieto and Santamaria 2007). In this regard, enterprises determine the feasibility of collaborations on the basis of opportunities and risks associated with each type of collaboration.

In order to understand the importance of universities' partnership within enterprises' innovation practices, it is necessary to address services, achievements, beneficiaries, expected results as well as understand that this process will be influenced by the environment, profiles of individuals/partner, and purposes (Barbero et al. 2014). In general, university support is highly effective in the creation and survival of knowledge-based enterprises (McAdam and McAdam 2008) because sharing unique sets of valuable and imperfectly imitable resources (financial and physical) and capabilities (human and organizational) (Kirby et al. 2011). However, in emerging countries, universities faces numerous limitations in quality and quantity of those resources and capabilities (Guerrero 
et al. 2014b). Nevertheless, universities are still key pillars in government efforts to reinforce the innovation ecosystem via subsidies designed to make science more relevant to industry's needs (Cohen et al. 2002; Herrera et al. 2016; Guerrero et al. 2016). Based on these arguments, this section focuses on discussing the role of universities in partnership with enterprises in innovation practices.

\subsection{University-enterprises' innovation practices motivated by strategic purposes}

Depending on strategic purposes, enterprises usually collaborate with science-based, commercial and mixed organizations (Alcalde and Guerrero 2016). Firstly, enterprises with an orientation towards radical innovations are involved in science-based collaboration with universities (Kenney and Mowery 2014; O’Connor and De Martino 2006). Traditionally, rather than intrapreneurial and commercial innovation practices, enterprise-university partnerships are characterized by an absorptive capacity of inflows knowledge as well as possibilities to access to R\&D public funding, qualified/specialized personnel, and technological capabilities (Cohen and Levinthal 1990; Belderbos et al. 2004; Colombo et al. 2004; Astrom et al. 2008; Olazarán et al. 2009). In this sense, the strategic purposes behind university-enterprise partnerships are learning/acquiring new external knowledge, technological regeneration, absorption of new skills, and development of radical or long-term innovations, through, for example, networking or outsourcing (Bonaccorsi et al. 2013; Kenney and Mowery 2014; Gassmann 2006; Grimaldi et al. 2011; Nambisan et al. 2012). Secondly, enterprises with an orientation towards incremental innovations usually are involved in commercial collaborations with different partners linked with the subsidiaries or with the industrial value chain (outflows of knowledge). Traditionally, rather than science-based innovation practices, commercial innovation practices are characterized by a fast return on investment, risk reducction, and enhancing flexibility, quality, and market adaptability (Chung et al. 2003; Tether 2002). In this regard, these innovation practices may also pursue non-technological objectives such as the identification of opportunities and expansion of the companies' markets, through internationalization or entry into new markets (Bayona et al. 2001; Tether 2002). Evidence suggests some advantage behind this type of innovation practices such as reduction of market uncertainty, outward licensing of intellectual property, capitalization of initiatives and return of investment (Lichtenthaler and Ernst 2007; Ritala and Hurmelinna-Laukkanen 2013; van de Vrande et al. 2009). Thirdly, according to achieve an effective exploration/exploitation of innovation, enterprises usually adopts diversified collaboration patterns. In this case, the purpose is a combination of partnerships that facilitates the generation of radical and incremental innovations (Alcalde and Guerrero 2016). Consequently, having a variety of commercial and scientific partners has a greater positive impact on the degree of novelty in products than collaboration with only one type of partner (Nieto and Santamaria 2007), especially within prosperity contexts. In emerging economies, limited access to various financial sources may generate negative enterprise dynamics due to insufficient entry of innovative enterprises in the market (Parker 2009; Nanda and Rhodes-Kropf 2013); for this reason, mixed collaborations facilitate the building of sustainable competitive advantages and support innovation performance (Laursen and Salter 2006), particularly for enterprises that are fighting for organizational survival, because optimal combinations of commercial and technical (scientific) skills reduce market uncertainty. Intuitively, in scenarios with unpredictable market conditions, enterprises will try to collaborate with several partners 
simultaneously in order to be competitive and innovative while sharing potential challenges and risks.

Hypothesis 1 In emerging economies, innovative enterprises are more likely to collaborate with universities to develop radical innovations than to develop incremental innovations.

Hypothesis 2 In emerging economies, the role of universities in exploratory innovation is more significant in science-based collaborations than in mixed collaborations with other agents.

\subsection{University-enterprises' innovation practices motivated by government subsidies}

Governments around the world have created subsidies or incentive innovation programmes to promote knowledge exchange (Bozeman 2000); especially, in emerging economies, where university-enterprise partnership is compulsory as a strategy to stimulate regional economic development (van de Vrande et al. 2009). In certain scenarios characterized by several constraints, the main policymakers' assumption is to transfer to universities and government research centres responsibilities linked to innovation and commercialization practices (Marzo et al. 2008) as well as to pay attention to industry's needs (Cohen et al. 2002). Even these policy makers intentions, subsidies or incentive innovation programmes also represent for universities and enterprises an excellent opportunity to develop subsidized innovation (de facto lowering the costs for all the participants in these initiatives) (Guerrero and Urbano 2016) as well as a risk to adopt an university-industry opportunistic when the relationship is relatively fragile and tend to be discontinued when the public funds for the initiative dried up (Gianiodis et al. 2016) or with the existence of opportunism from intermediaries when governments use them as a bridge between enterprises and public funding (Armanios et al. 2016).

Overall evidence on university-enterprise innovation practices is thinly spread and further research and analysis is warranted (Feller 2005; Perkmann et al. 2013). Neither theoretically nor empirically, there is a definitive justification and evidence about the effectiveness of public R\&D subsidies in stimulating private/collaborative R\&D as well as in resulting of significant and tangible outcomes (Greco et al. 2016; Hall et al. 2016). The proponents of $\mathrm{R} \& \mathrm{D}$ programs consider that subsidies enhance firm productivity, reinforce domestic economic growth, generate spillovers, and increase private R\&D expenditures (Dimos and Pugh 2016). In this point of view, subsidies give the opportunity to an individual enterprise or a collaboration partnership to turn an unprofitable project into a profitable one or complete an existent project. Enterprises may view public funds as are relatively cheap way to finance their $R \& D$ projects, especially when application costs are low and the probability of selection is high compared to alternative financing sources (Aschhoff 2009; Aschhoff and Sofka 2009). As a result, subsidies reduce the fixed costs of other current and future research projects and increasing their probability of being completed or undertaken (Benavente et al. 2007). The opponents of R\&D programs argue that the subsidies are not diverted to the best firms because the selection of subsidized firms could influence by pressure groups (Hall et al. 2016) or by the information asymmetry between firms and investor generates difficulties in measuring the private and social returns of R\&D projects (Callahan et al. 2012). In this point of view, some studies also recognized that the majority of subsidized firms are selected more on the basis of achieving political, economic and strategical government's purposes than on the basis of the project quality 
(Sissoko 2011). However, evidence also support the existence of long-standing partnerships between universities and enterprises, and the fact that universities continue to aggressively seek industrial sponsorship, although government subsidies and grants create strong administrative burdens for companies, as government support is considered to be highly inflexible, since it does not allow to change partners and the programs cannot end before a given date (van de Vrande et al. 2009).

Even those perspectives, subsidies provide resources for the development of projects involving universities and enterprises. There are several examples such as the European Commission framework programmes (Caloghirou et al. 2001); federally-funded schemes such as the Advanced Technology Program in the US (Hall et al. 2001); funding instruments provided by research councils and government departments in the UK (Howells et al. 1998); federal university-industry projects in Germany (Almus and Czarnitzki 2003; Czarnitzki et al. 2007); among others. In fact, Bellucci and Pennacchio (2016) analysed enterpriseuniversity partnerships across European countries and they found that environmental context explain the effectiveness of those innovation practices as well as confirm that enterprises are more likely to collaborate with universities when are looking for radical innovations. Similarly, previous studies have estimated the effect of public subsidies on the promotion of R\&D activities and university-enterprise cooperation (Segarra-Blasco and Arauzo-Carod 2008), and have concluded that enterprises with access to such public subsidies tend to cooperate with one another (Cassiman and Veugelers 2002). Current researches in the field are paying more attention on university-enterprise partnership across emerging economies providing interesting insights concerning dilemmas experimented in university-enterprise partnership for innovation purposes in Brazil (Bastos et al. 2014), exploring the role of intermediaries in the innovation process in China (Armanios et al. 2016), the partnership intensity influenced by the technological change and expected profitability translation of innovative effort in Vietnam (Santarelli and Tran 2016), the elements like reputation and national priorities that defined the incentives that drives innovation partnerships in South African (Kruss and Visser 2017). Based on these arguments, in emerging economies where public subsidies are oriented to reinforce enterprise-university collaborations, we expected to find that these government intervention allows an effective exchange of knowledge, generation of radical innovations and spillover effects (Astrom et al. 2008; Boschma 2005; Brenes et al. 2016; Perkmann and Walsh 2007; Perkmann et al. 2013). Indeed, this expected effect will be reinforced when enterprises develop mixed innovation practices simultaneously with universities and other enterprises (Alcalde and Guerrero 2016).

Hypothesis 3 The access to government subsidies with compulsory university partnerships is greater in exploratory innovation practices than in exploitative innovation practices.

Hypothesis 4 The access to government subsidies with compulsory university partnership is greater in mixed collaborations than in exclusively science-based collaborations.

\section{The Mexican science, technology and innovation ecosystem}

Emerging economies have assuming an increasingly prominent position in the world economy because comprise countries ${ }^{1}$ with a rapid pace of development and government policies that favor economic and the transition towards an entrepreneurial and knowledge societies (Herrera et al. 2016; Hoskisson et al. 2000; Guerrero and Urbano 2016; Miller 
et al. 2016; Wright et al. 2005). Classified by the International Monetary Fund, Mexico is an interesting example of an emerging economy by the economic, political and social initiatives implemented during the last three decades (Guerrero and Urbano 2016). Based on the objectives of this research, this section tries to provide some elements that allows understand antecedents and initiatives linked to the configuration of the Mexican Innovation Ecosystem.

\subsection{Antecedents and elements}

In 2002, the Mexican government enacted the Science and Technology Law with the objective to foster scientific research, technological development, and innovation. The main body responsible for defining, developing, and implementing the law was the National Council for Science and Technology (CONACYT), in collaboration with other government organizations. According to the Diario Oficial (2014), the main elements of the Mexican Science, Technology and Innovation System are the laws and normative, Mexican Government, CONACYT, Industry, Higher Education, Society and other organizations. In general, the Science and Technology Law offered a great opportunity for Mexican companies to maximize benefits and develop a virtuous cycle of wealth generation as well as the creation of universities' units to foster technological development, innovation projects and linkages with productive sectors and services (i.e., similar to technology transfer offices, TTO). Within this context, the government directly provides enterprises with mechanisms and programs to support innovations, business creation, and human capital, and does the same for universities oriented to solve social problems or focused on economic priorities. Several subsidy programs have been implemented to support innovation, with a strong participation by the CONACYT, the Ministry of Public Education, and the Ministry of Economy. As a result, universities actively collaborate in specific projects or provide services based on their teaching, research, and entrepreneurial activities (supply-side), while enterprises make specific demands aimed at the development and transfer of knowledge via new products/services, as well as innovations in managerial processes (demand-side).

\subsection{Incentives for fostering innovation and enterprise-university partnerships}

According to the OCDE's Science, Technology and Industry Scoreboard (OECD 2013), the Mexican economy evidenced the highest percentage of product and/or process innovative enterprises receiving direct public subsidies for innovation during 2008-2010. However, the investment in science and technology represents $0.79 \%$ of the Mexican GDP oriented to experimental research and development, for the education and training of scientists and technicians, and for scientific and technological services CONACYT (2011). Concerning the promotion of enterprise-university partnerships, during 2009-2016, Mexico has created the Incentive Programme for Innovation and has investment more than 2932 millions of dollars (54\% from private funds and $45 \%$ from public funds. Figure 1 shows the R\&D investment per year as well as the distribution of subsidized projects per priority industries.

According to the CONACYT, ${ }^{1}$ the Incentive Programme for Innovation is oriented to support enterprises that are registered at the National Register of Institutions and Scientific

1 For further information, visit [http://conacyt.gob.mx/index.php/fondos-y-apoyos/programa-de-estimulosa-la-innovacion]. 


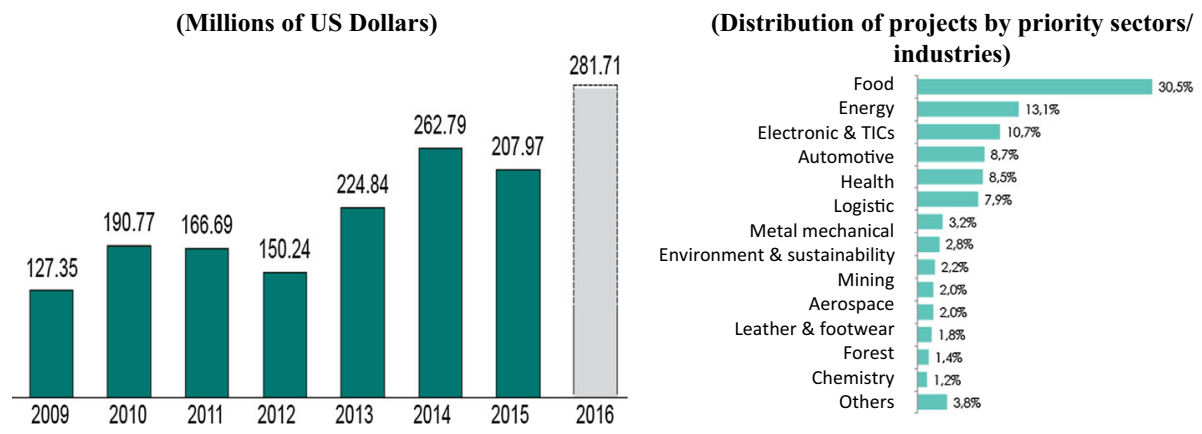

Fig. 1 Government investment in the Incentive Programme for Innovation. Source: CONACYT Statistics

and Technological Enterprises (RENIECYT) for conducting research and investing in the development of new technology and innovation, individually or in association with public/ private university or research center, at national level. Specifically, the main aim of this incentive is to encourage growth, competitiveness, links between enterprise and scientific organizations (universities \& research centers), incorporate specialized human capital, generate innovations (new products/services, process) with value added to strategic sectors, and contribute to the creation/protection of intellectual property. The Incentive Programme for Innovation includes three modalities: (a) INNOVAPYME (Technological Innovation for Micro, Small and Medium Enterprises) oriented to projects promoted by SMEs both individually or/and in collaboration with a university/research center; (b) INNOVATEC (Technological Innovation for Large Enterprises) oriented to projects promoted by large enterprises both individually or/and in collaboration with a university/research center; and PROINNOVA (Projects Innovation-Oriented Network) oriented to proposal that are submitted in collaboration with at least two universities or two research centers or one university and one research center.

\section{Methodology}

\subsection{Data}

Aligned with the purpose of this research and previous researchers (Herrera et al. 2016; Guerrero and Urbano 2016; Santiago et al. 2016), we used the 2012 Research and Technological Development Survey (ESIDET, Encuesta sobre investigación y desarrollo tecnológico). This is a cross-section dataset that contains 10,167 enterprise-level data collected by the Mexican Institute of Statistics (INEGI) ${ }^{2}$ to enhance the statistical information on enterprise innovation activities. According to the ESIDET' methodology, the population of enterprises is identified in the Mexican economic censes. Based on this information, a probabilistic and stratified sample (enterprises with 20 or more employees distributed by productive levels and by Mexican geography) with an assumed statistical error of less than $5 \%$ or $8 \%$ is estimated. This survey is biannual and the main respondents are the owners/managers of those enterprises. Based on this methodological design, INEGI

\footnotetext{
2 According to the articles 37, 38 and 45 of the Mexican Law on National Statistics System and Geographic Information, the Mexican statistical data collected by the Mexican Institute of Statistics (INEGI) is strictly confidential and mandatory.
} 
ensures the enterprises' selecting process without a previous distinction in the development of innovating or non-innovating activities. This avoids bias in the results obtained with this dataset as suggested previous studies (Alcalde and Guerrero 2016; Bayona et al. 2001; Fritsch and Lukas 2001).

\subsection{Variables}

In order to analyze the importance of universities' partnerships in enterprises' innovation processes, and on the basis of previous studies (Alcalde and Guerrero 2016; Bellucci and Pennacchio 2016; Herrera et al. 2016; Nieto and Santamaria 2007; Yamin and Otto 2004), we created a categorical dependent variable (Collaboration) that takes the following values: 1 if the enterprise does not collaborate with any type of agents; 2 if it collaborates only with intrapreneurial agents (subsidiaries or corporate units); 3 if it collaborates only with commercial agents (enterprises); 4 if it collaborates with scientific agents (universities); 5 if it collaborates with both types of partners. The reference group was category 1 integrated by those enterprises that do not collaborate with any type of agents. In addition, these categories also allow us to do the analysis by exploitation processes (represented by collaborations with intrapreneurial and commercial agents) and exploration processes (linked to collaborations with scientific agents).

Concerning the independent variables, following De Fuentes and Dutrénit (2016) and Ritala and Hurmelinna-Laukkanen (2013), the first set of independent variables called "incremental and radical orientation". Given survey design, we used a proxy to identify the enterprises' orientation towards the development of incremental innovations (substituting current products, improving product quality, entering into new markets, improving the production process) or radical innovations (new product lines). In particular, these proxies were measured using a Likert Scale $(1=$ lower orientation and $4=$ higher orientation). Moreover, as was explained in Sect. 2 and 3, a traditional way to foster innovation in emerging economise such as Mexico is via public subsidies or incentive programmes (Cohen et al. 2002; Czarnitzki et al. 2007; Dimos and Pugh 2016; GarcíaQuevedo 2004; Perkmann et al. 2013; Perkmann and Walsh 2007). In this line, the second set of variable called "subsidies granted" that takes into consideration the relevance of accessing to public subsidies for innovation practices, whether these subsidies require compulsory university partnerships (Gob support with Universities) or not (Gob support individually without any partnership). The 2012 ESIDET survey includes a list of public innovation support programs, and this allows us to build these two variables according to the number of subsidies received from the government.

Regarding control variables, based on the data available for this study, we used control variables related to certain firm-level strategic and structural characteristics (Perkmann et al. 2013; Perkmann and Walsh 2007). Firstly, one of the main criticisms of the dynamic capabilities concept is that these capabilities are difficult to measure empirically, and the same is true for underlying operational processes such as innovation practices. In this study, we controlled the "strategic characteristics" using proxies that could represent the capabilities that enterprises require to grow and survive, based on their objectives, resources and barriers (De Fuentes and Dutrénit 2012; Dutrénit et al. 2010; Easterby-Smith et al. 2009; Narayanan et al. 2009; Scuotto et al. 2016). In the ESIDET survey, measured with a Likert Scale (1-4), we identified some proxies that captured the relevance of certain objectives for enterprises' innovation practices (e.g., to reduce variable costs, reduce fixed costs, reduce damage to the environment, comply with standards and regulations, and reduce the use of inputs) as well as the identification of certain obstacles for enterprises' 
innovation practices (e.g., economic risks, high innovation costs, access to financial sources, internal rigidity, lack of qualified personnel, lack of technology updates, lack of market information, legislative obstacles, and lack of customer responsiveness). Secondly, we also included several variables related to the structural characteristics that determinate enterprises' innovation practices according to the product life cycle, access to resources and the barriers (Alcalde and Guerrero 2016; Cohen and Klepper 1996; De Fuentes and Dutrénit 2012; Dutrénit et al. 2010; Hewitt-Dundas 2013; Santiago et al. 2016): Enterprise's age measured with a dummy variable that indicates that the enterprise has less than 5 years old (1) or more than 5 years old (0); Availability of innovation resources measured by the investment in $R \& D$ expressed in pesos and the number of qualified personnel; Enterprise size measured as the number of employees and expressed in logarithms; Exports measured by means of a dummy variable where 1 represents those enterprises that have exported and 0 otherwise; Company group measured by a binary variable that takes a value of 1 if the enterprise is a part of a company and value 0 if it is a single-unit enterprise; Technological sector using a binary variable to identify if enterprise innovates influenced by technological sectors or not; and finally, we also controlled the location, including the entrepreneurial density of the state where the enterprises developed their economic activities.

\subsection{Method}

Based on the categorical nature of our dependent variable, we estimated a multinomial logistic regression model (Greene 1992). In particular, the categorical dependent variable is defined in such a way that it has five different values ( 1 for no collaboration; 2 for intrapreneurial collaboration; 3 for commercial collaboration; 4 for scientific collaboration, and 5 for mixed collaboration). A multinomial logistic regression requires careful consideration of the sample size and examination of the outlying cases. Therefore, given the low number of companies that generate innovation in emerging economies, our reference group was no collaboration as follow:

$$
\operatorname{Pr}(y=k)=\frac{\exp \left(\alpha+\beta^{\prime} X_{i j}\right)}{\sum_{J=1}^{5} \exp \left(\alpha+\beta^{\prime} X_{i j}\right)} k=1,2,3,4,5 .
$$

Table 1 shows the main descriptive analysis for all the variables. During 2011 and 2012, only $9 \%$ of the Mexican enterprises surveyed implemented collaborative innovation practices. The majority of these enterprises collaborated with intrapreneurial partners, such as subsidiaries or companies in the same group. By contrast, in a developed economy like Spain's, on the basis of a similar sample of enterprises, the percentage of innovative collaborating enterprises is about 35\% (Segarra-Blasco and Arauzo-Carod 2008; Barge-Gil 2010). A robustness test was also developed to ensure that our results are similar to, and consistent with, the enterprises' performance profiles, and, on the basis of the criteria to identify high-growth entrepreneurship (Audretsch 2012; OECD 2007, 2010), ${ }^{3}$ we tested the model with two sub-samples: (i) enterprises that did not grow by more than $20 \%$ in either total sales or personnel during 2011-2012 (7339 enterprises), and (ii) enterprises that grew

\footnotetext{
3 The OECD-Eurostat Manual on Business Demography Statistics (2007) defines a high-growth enterprise as an enterprise with an average annualized growth greater than twenty percent per annum, over a three-year period, and with ten or more employees at the beginning of the observation period. Growth is thus measured by the number of employees and by turnover. In our study, we used a proxy for this concept because we only had information available from the previous and the current year.
} 


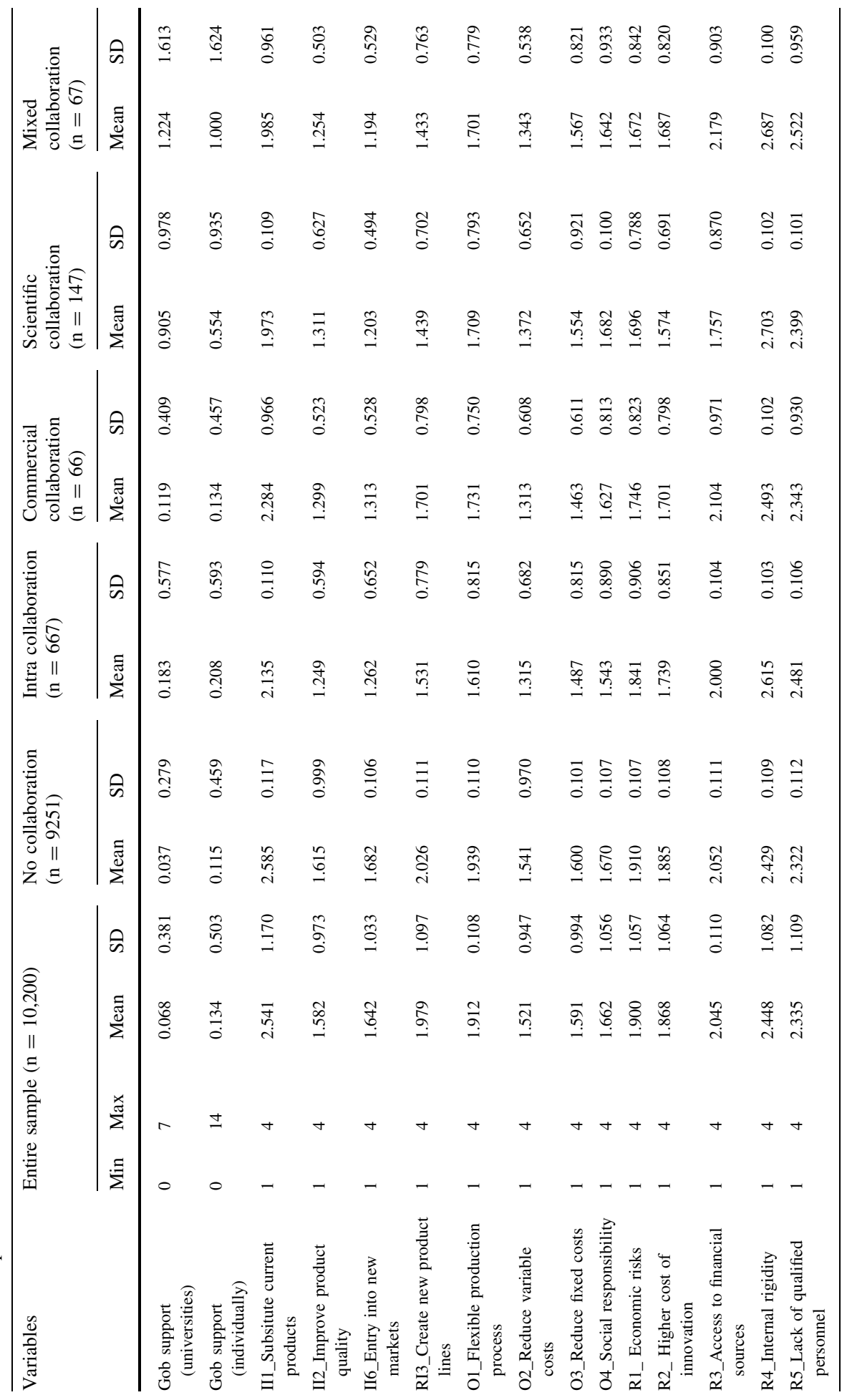




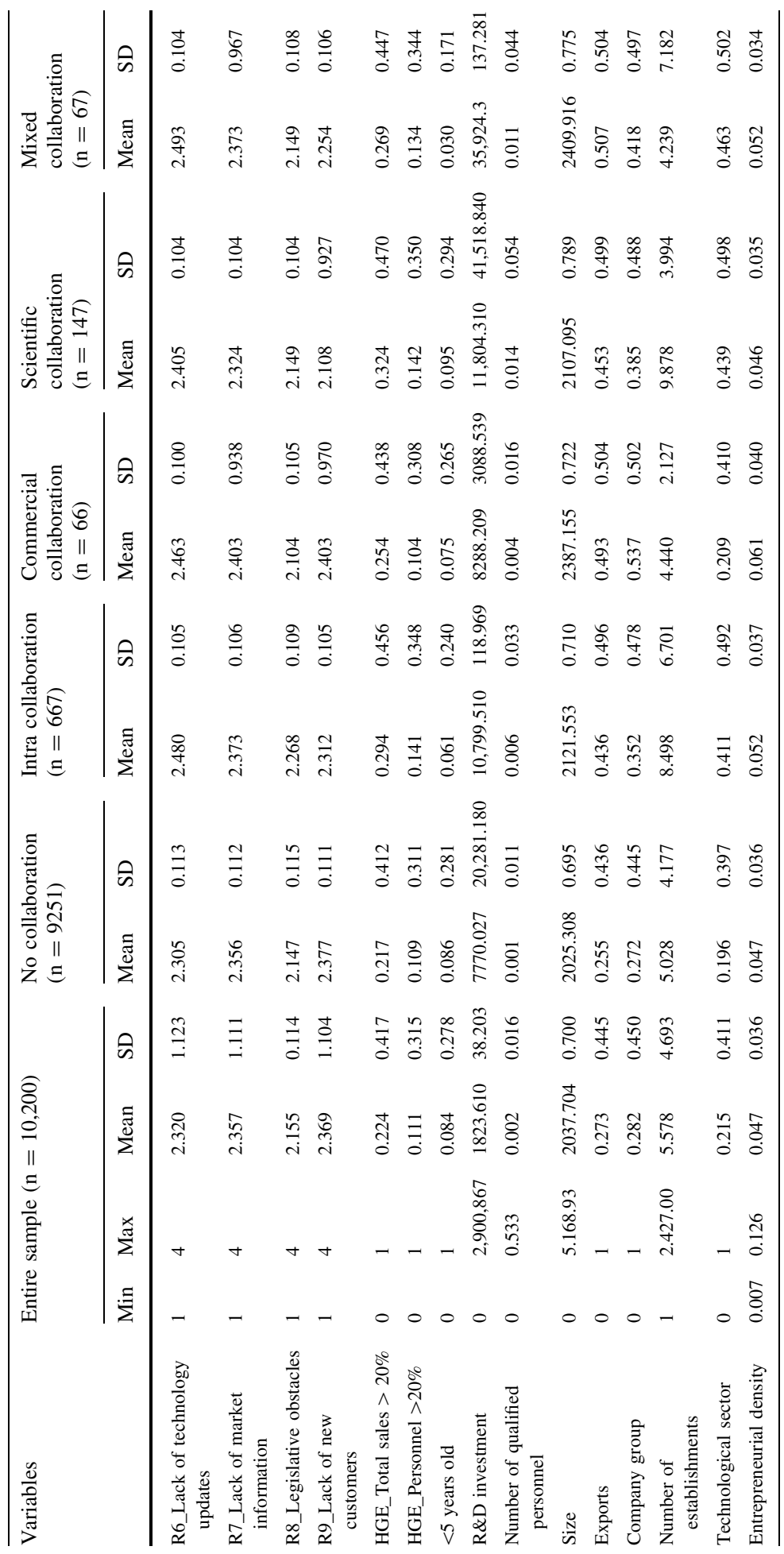


by more than $20 \%$ in terms of both total sales and personnel during 2011-2012 (1684 enterprises).

\section{Exploring Mexican enterprise-university partnerships}

Table 2 presents the main results obtained from the multinomial regression model that analyzes the role of Mexican universities in the development of exploratory and exploitative innovation practices.

\subsection{Innovation practices motivated by strategic purposes}

In the case of non-innovative enterprises, the probability that an enterprise has sciencebased collaboration agreements with universities increases by 0.70 when the enterprise is interested in developing radical innovations associated with new product lines $(0.349$; $p<0.050$ ), whereas the probability decreases by 0.77 and 0.52 when it is primarily interested in substituting current products $(-0.259 ; p<0.050)$ and entering into new markets $(-0.555 ; p<0.050)$, respectively. When we analyze the control variables, science-based collaboration increases when the enterprises have lower access to financial sources or face internal rigidity, legislative obstacles, or a lack of customer responsiveness. In this case, having an absorptive capacity facilitates the implementation of radical innovations, because this enables the exchange of existing knowledge and a combination with the new knowledge provided by the universities (Kenney and Mowery 2014). These results are consistent with previous studies, which have shown that science-based practice focuses not only on supporting final product innovation but also provides a new scientific knowledge base aimed at radical innovations (O'Connor and De Martino 2006). Enterprise-university collaborations allow have access to new/advanced knowledge and technological resources required to explore new opportunities and initiatives for achieving radical innovation strategies (Guerrero et al. 2016). In fact, Dutrénit et al. (2010) and Cárdenas et al. (2012) also evidenced similar channels knowledge transfer and collaboration strategies between Mexican universities and enterprises. Therefore, similarly than developed economies, we also find similar motivations and aspirations inside universityenterprise partnership but generally the benefits are observed in long-term (De Fuentes and Dutrénit 2012) and depend of the geographic proximity (De Fuentes and Dutrénit 2016).

On the other hand, the probability of developing incremental innovations increases by between 0.77 and 0.85 when an enterprise engages in intrapreneurial partnerships, particularly when it is focused on substituting its current products/services $(0.160 ; p<0.001)$, improving the quality of its current products $(0.263 ; p<0.001)$, and entering into new markets $(0.261 ; p<0.001)$. This type of collaboration provides valuable sources of information for developing/improving products and enhancing flexibility, product quality, and market adaptability (Chung et al. 2003). When we analyze the rest of the control variables, we find that the lack of qualified personnel and technological updates, and the existence of legislative obstacles increase the probability of developing internal collaborations. These results confirm the findings of previous studies, which have demonstrated that a lack of financial resources encourages exploiting innovation practices with commercial partners rather than with scientific partners (e.g. purposive outflows of knowledge) (Lichtenthaler and Ernst 2007; van de Vrande et al. 2009). Therefore, the evidence supports hypothesis $\mathrm{H} 1$, which states that, in emerging economies, innovative enterprises are 


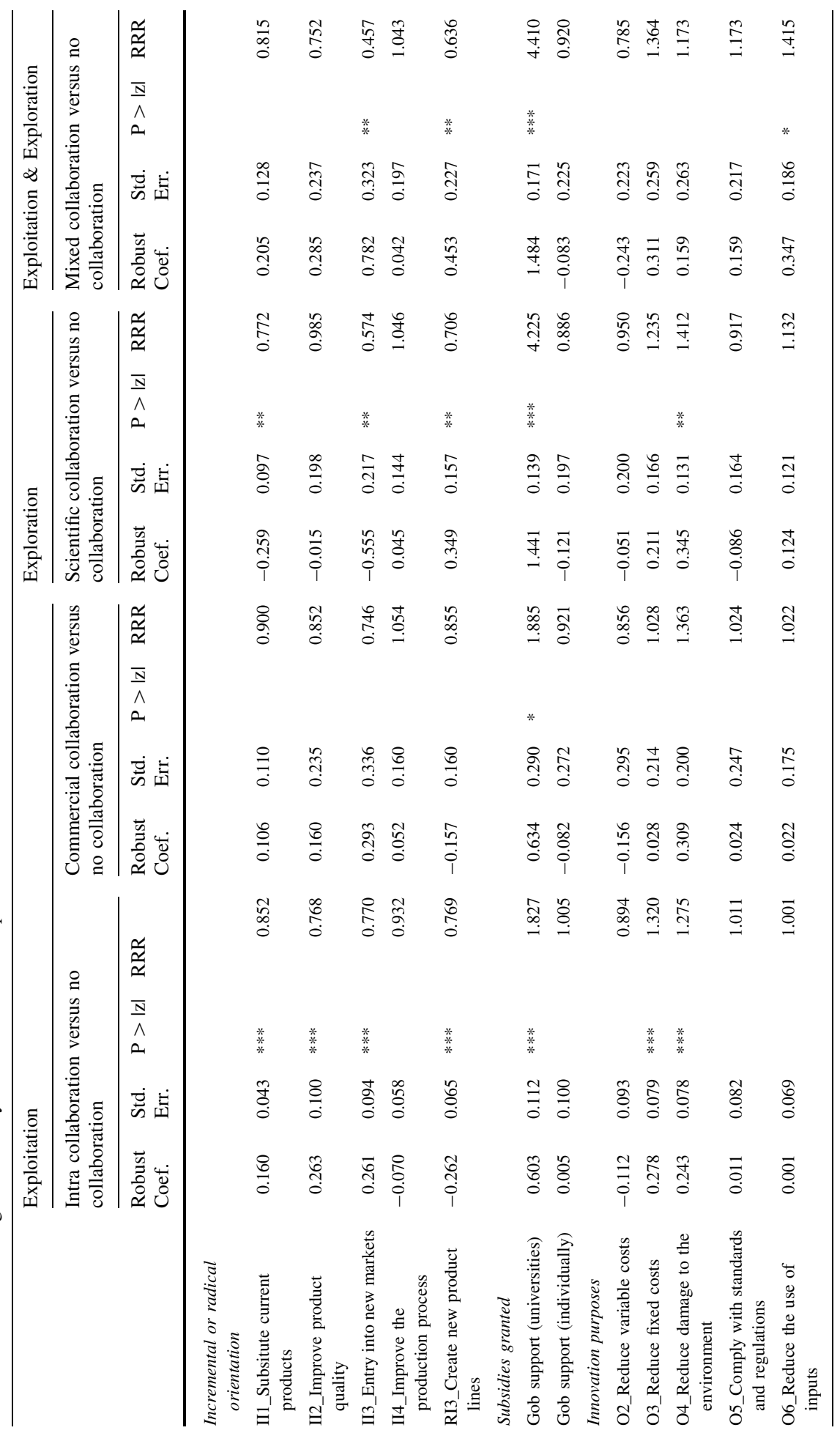




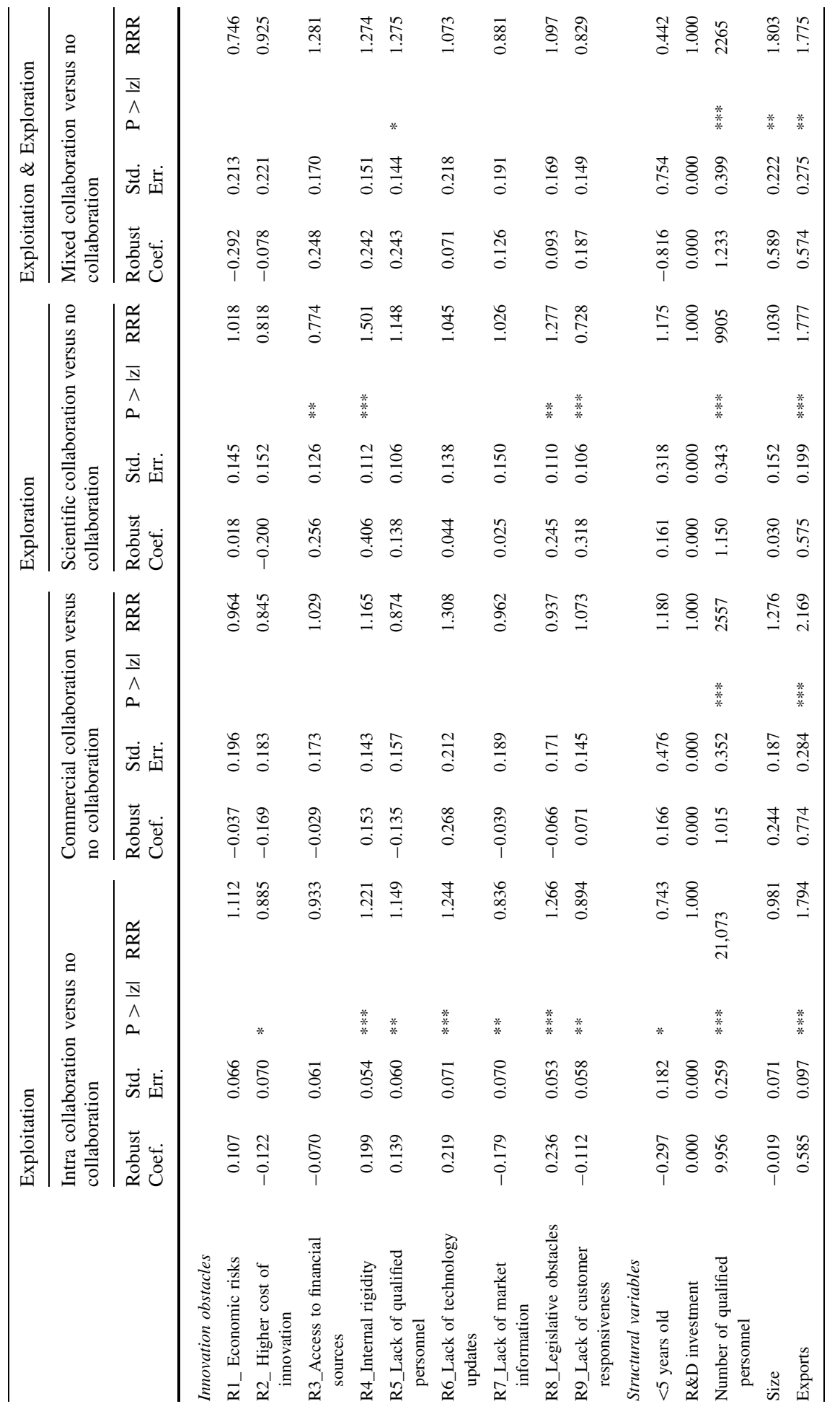




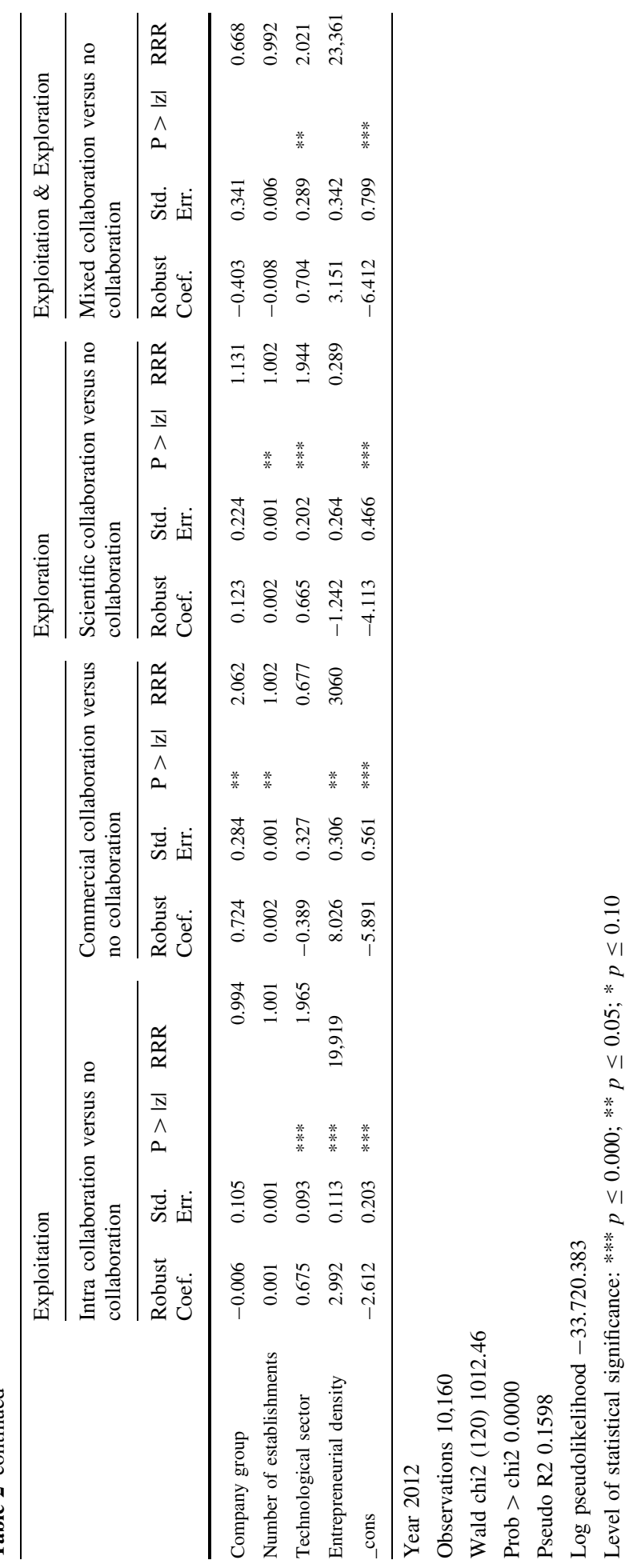


more likely to collaborate with universities to develop radical innovations than to develop incremental innovations. Taking non-innovative enterprises as a reference, the evidence suggests that the probability that Mexican enterprises collaborate with both universities and other internal/external agents increases by $0.457(0.782 ; p<0.050)$ when the enterprises have an incremental innovation orientation (exploitation with other agents) and by $0.636(0.453 ; p<0.050)$ when they have a radical innovation orientation (exploration with universities). As previous studies have shown, mixed collaboration allows to effectively explore/exploit new opportunities (Alcalde and Guerrero 2016) and entails great benefits for enterprises with innovation patterns and encourages the creation of novel products (Becker and Dietz 2004). Interestingly, the control variables showed that enterprises choose this type of collaboration when they are interested in reducing the use of inputs and lack qualified personnel. Particularly, in the case of Mexico, enterprises faced several challenges particularly associated with the lack of qualified human resources, funds, and productivity (Cárdenas et al. 2012). In general, these enterprises belong to the technological sectors and have an exporting profile. Under these conditions, diverse collaborations facilitate building sustainable competitive advantages, because they provide a good combination of commercial and technical (scientific) skills, thereby reducing market uncertainty (Laursen and Salter 2006). As compared to science-based collaboration, the probability of university involvement in exploratory innovation with enterprises and other agents is lower than for involvement in exclusively scientific-based partnerships. This evidence supports hypothesis $\mathrm{H} 2$.

\subsection{Innovation practices motivated by government subsidies}

In regards to compulsory enterprise-university partnerships as a condition to receive government subsidies, and taking non-collaborative enterprises as the reference group, the results show that compulsory enterprise-university partnerships increase by $1.827(0.603$; $p<0.001)$ the probability to collaborate with intrapreneurs, by $1.885(0.634 ; p<0.001)$ with commercial agents, by $4.22(1.441 ; p<0.001)$ with scientific agents, and by 4.41 $(1.484 ; p<0.001)$ with mixed agents. These results support hypotheses H3 and H4. According to Cohen et al. (2002), this government strategy is aimed at reorienting university research towards the needs and realities of enterprises. In this scenario, the direct positive effect behind these strategies is that universities reinforce and legitimize their role in social and economic development (Guerrero et al. 2015) and enterprises obtain access to otherwise scarce financial resources for innovation (Caloghirou et al. 2001), as well as knowledge transfer and successful innovation processes (Boschma 2005). Indirect effects may include the generation of spillovers (Perkmann et al. 2013; Perkmann and Walsh 2007) and long-standing partnerships (van de Vrande et al. 2009). Therefore, any financial decision represents a higher cost/risk for enterprises and the main innovation constrain in emerging economies (Álvarez and Crespi 2015; Crespi and Zúñiga 2012). In particular, Mexican enterprises are more likely to use internal innovation funds (e.g., retained earnings and parents' support) than external sources (e.g., other enterprises) (Guerrero and Urbano 2016). In fact, Autio et al. (2014) argue that radical innovations among enterprises-universities use multiple and combined sources of funding (public/private). Therefore, government subsidies with compulsory university partnership are other enterprises' motivation and contribution from universities in the development of explorative innovation projects. 


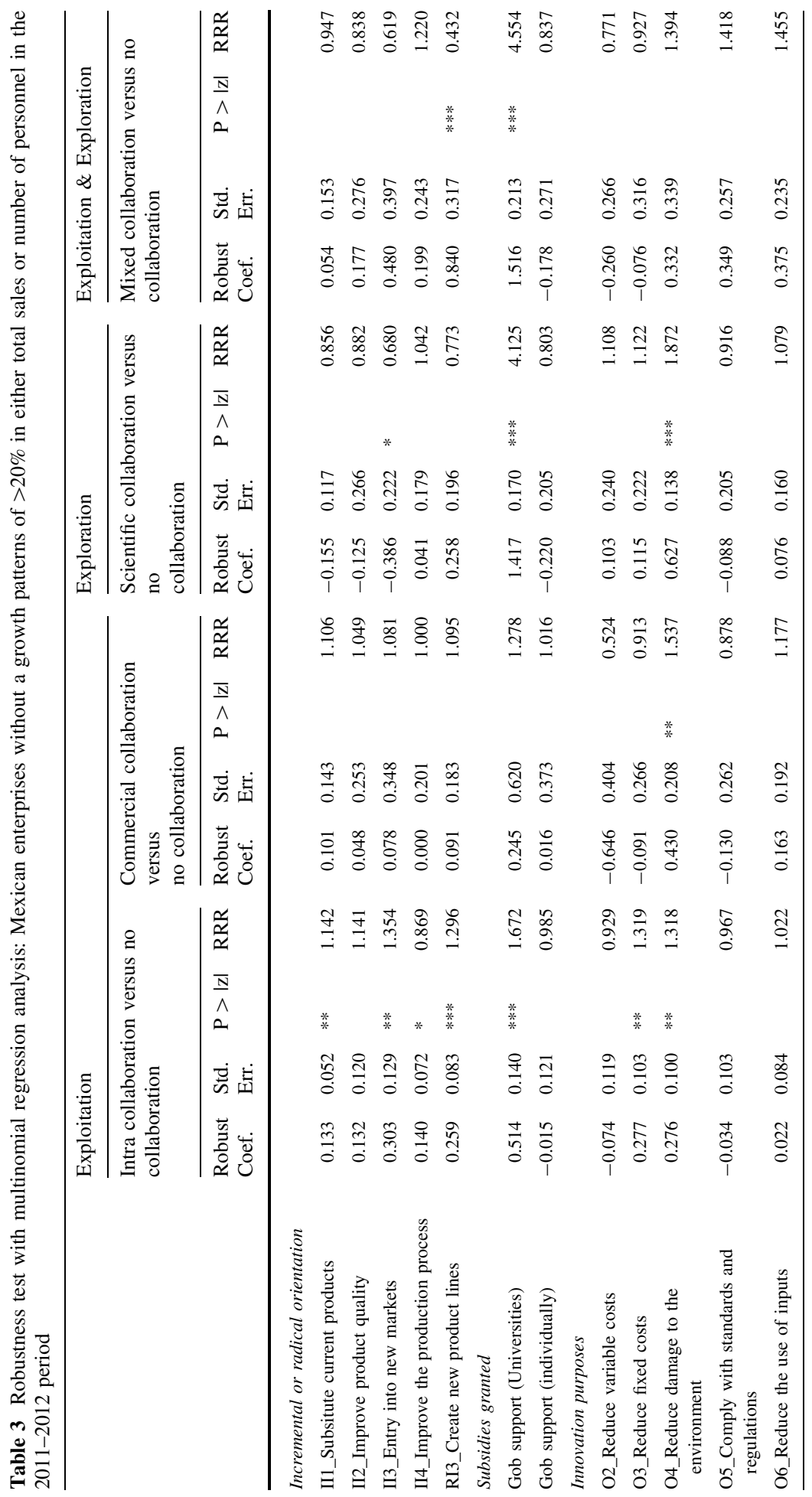




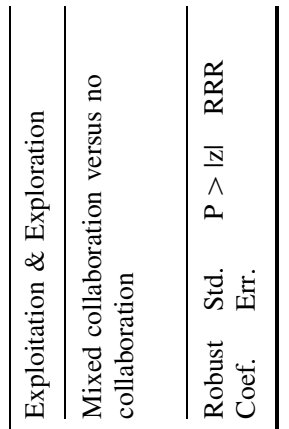

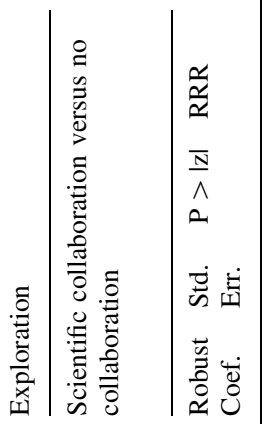

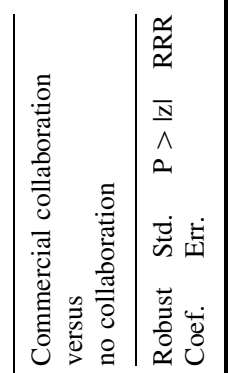

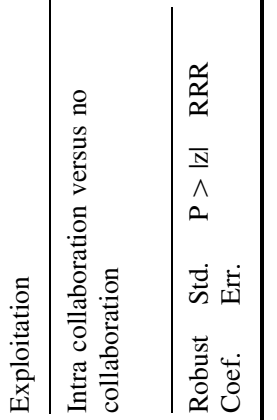

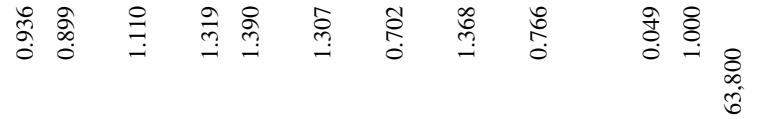

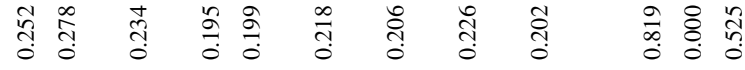

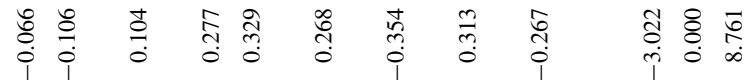

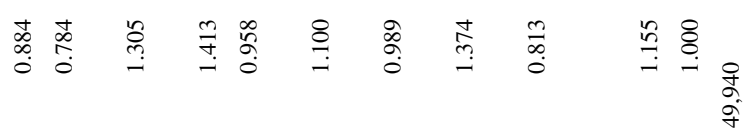

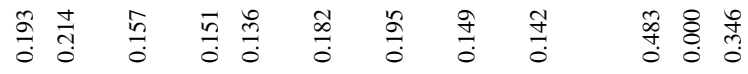

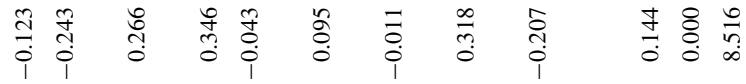

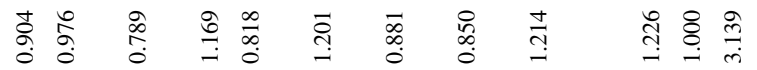

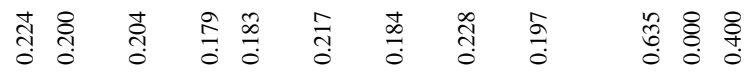

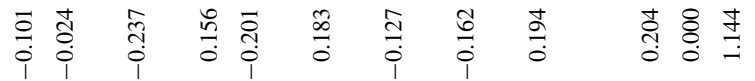

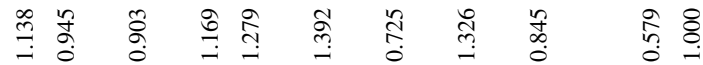

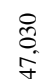

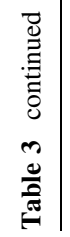

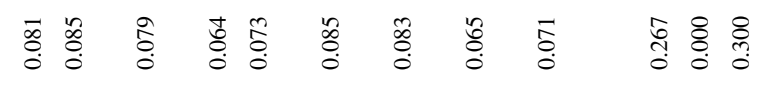

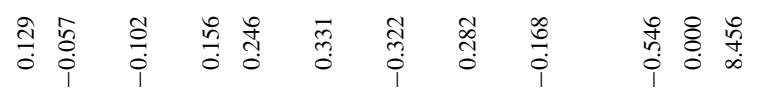

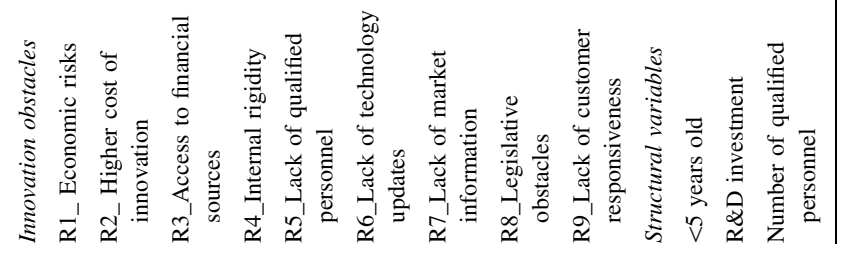




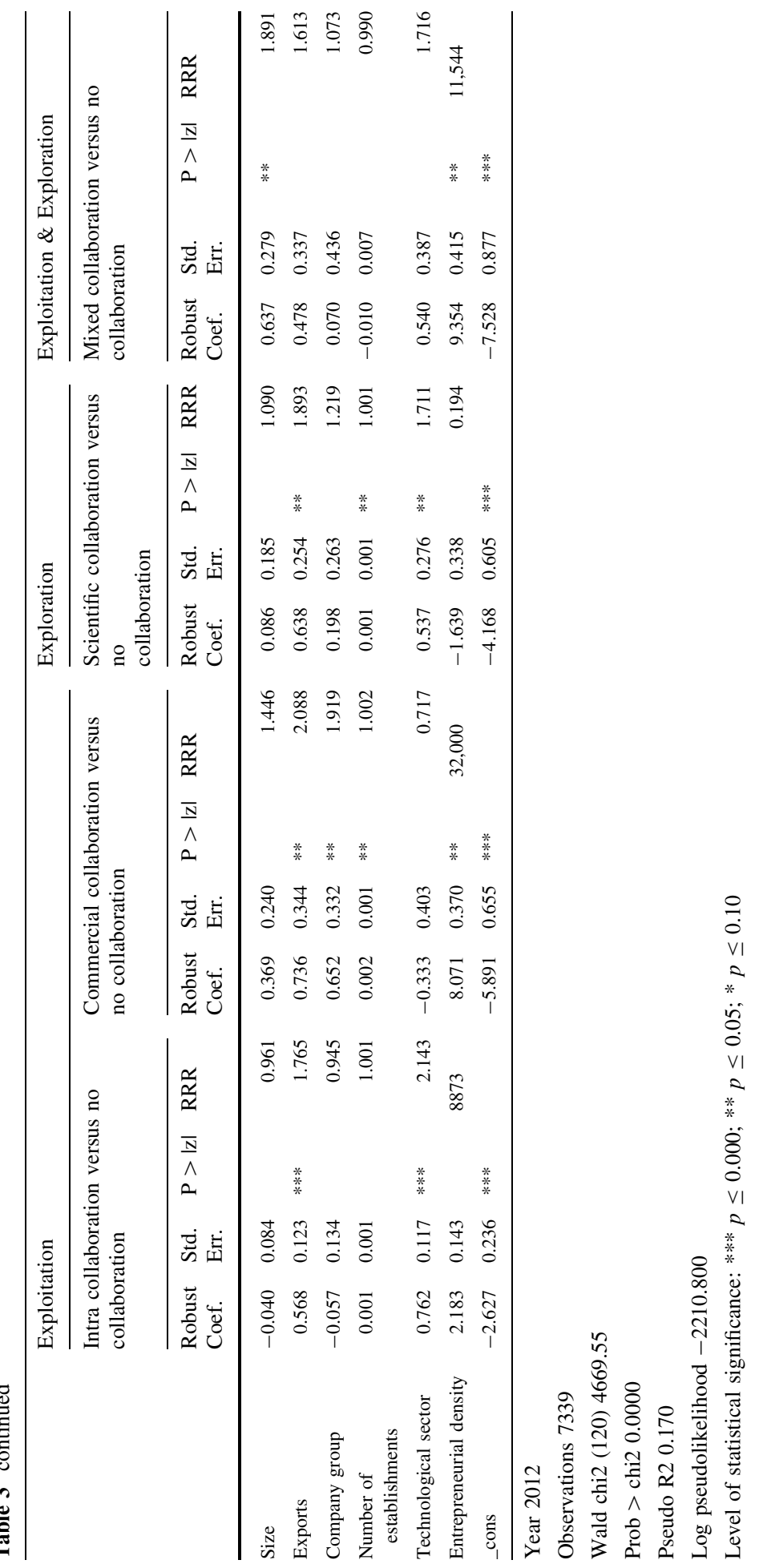




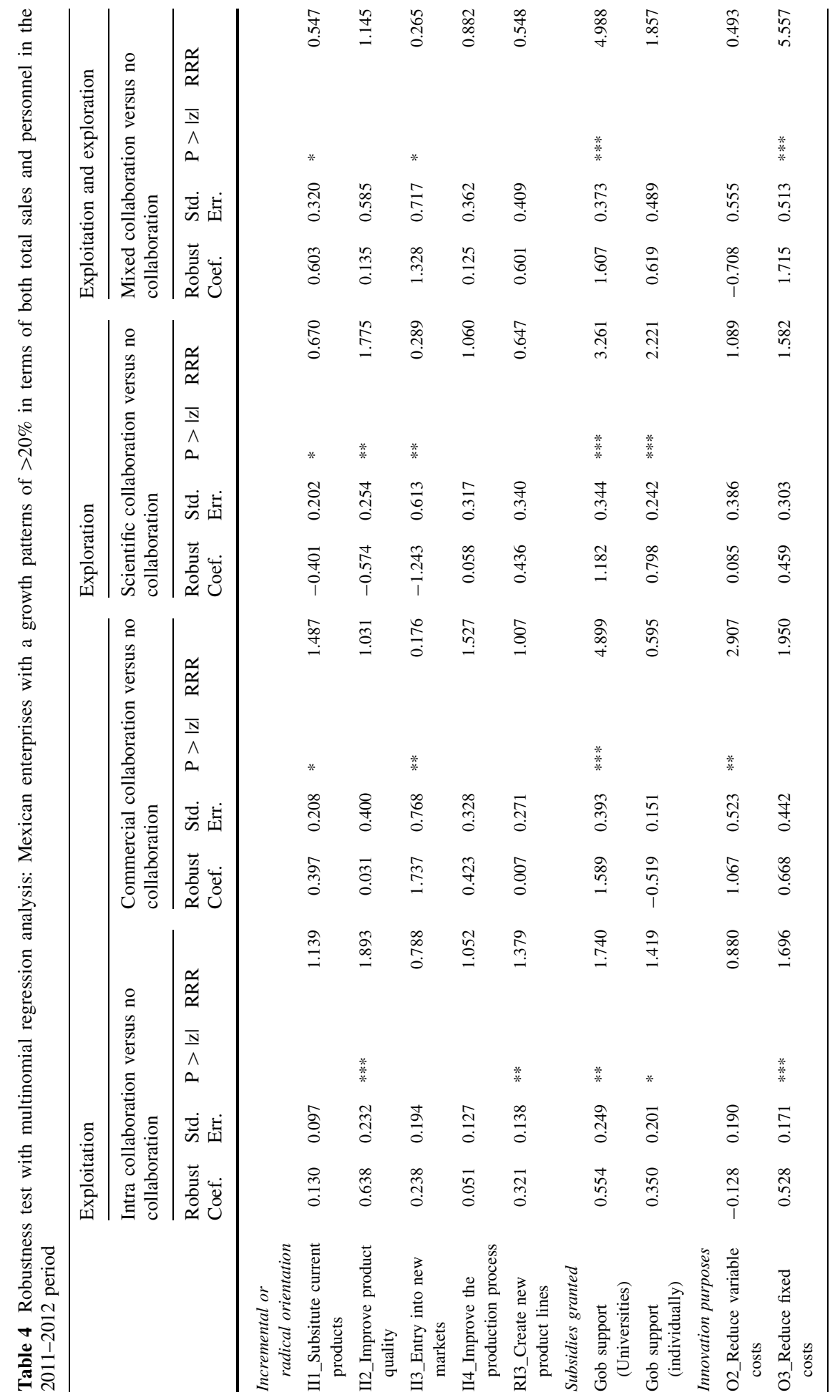




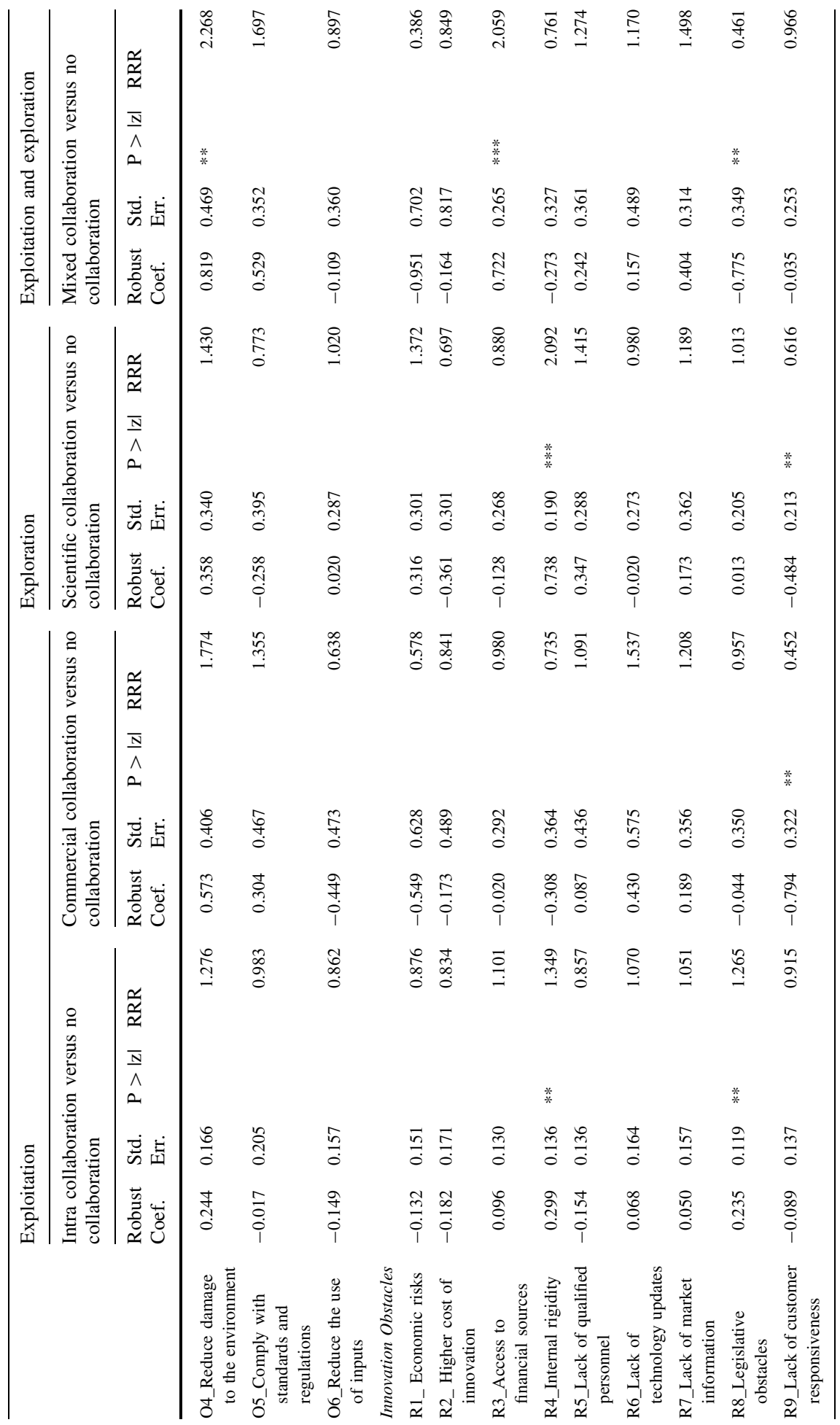




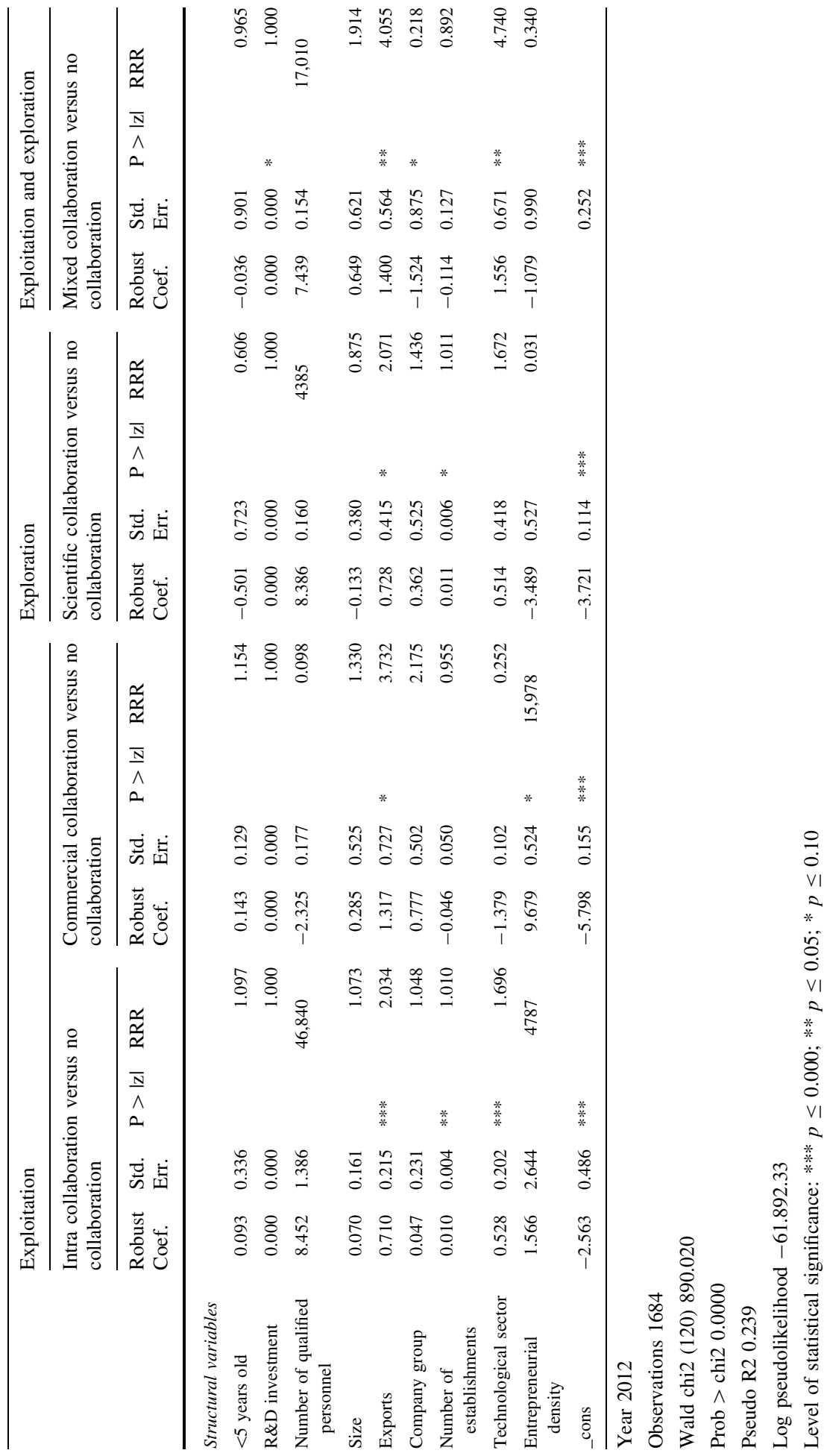




\subsection{Robustness check}

The prior literature suggests that the main motivations for enterprises engaging in collaborations are the potential innovation outcomes that may be obtained in terms of performance (Hagedoorn 1993), technological evolution (Rosenkopf and Nerkar 2001), and new product introduction (Laursen and Salter 2006). On the basis of this argument, and in order to corroborate our findings, Tables 3 and 4 include a robustness check. We tested our model in two sub-samples built following the criteria of high-growth entrepreneurship proposed by the OECD $(2005,2010)$. The main purpose was to understand the role of universities in enterprises that did not grow as compared to enterprises that grew by $>20 \%$ in terms of sales and personnel. In general, the results obtained in these robustness tests confirmed our hypotheses ( $\mathrm{H} 1, \mathrm{H} 2, \mathrm{H} 3$, and $\mathrm{H} 4)$. In fact, we identify that universities play a relevant role in emerging economies because produce positive effect on enterprises' innovation and it is reinforced when these enterprise has a high-growth orientation. This means that the group of enterprises with a strong orientation to growth in both employees/ sales is influenced by university relationships that motivate to develop more entrepreneurial and novel innovations as suggested Autio et al. (2014) and Van Dijk and Van den Ende (2002). Interestingly, Latin American emerging economies are characterized by a limited number of high-growth orientation enterprises as a result of several environmental restrictions to create knowledge-based enterprises (Acs and Amorós 2008) (Table 5).

Table 5 Summary of results obtained

\begin{tabular}{lll}
\hline $\begin{array}{l}\text { Enterprises } \\
\text { partnership with }\end{array}$ & Orientation toward & Exploitative \\
\cline { 2 - 3 } Scientific & Explorative & \\
& $\begin{array}{l}\text { New knowledge (inflows) } \\
\text { Radical innovations }\end{array}$ & \\
& Long term innovations & \\
& Access of resources and capabilities \\
& Access to public funds or subsidies with & \\
& compulsory partnership & \\
& & New opportunities (outflows) \\
Commercial & & Incremental innovations \\
& & Short term solutions \\
& & Reduce risk, investments and \\
& & increase returns \\
Mixed & New knowledge (inflows) & New opportunities (outflows) \\
& Radical innovations & Incremental innovations \\
& Long term innovations & Short term solutions \\
& Access of private and public resources & Reduce risk, investments and \\
Access to public funds or subsidies with & increase returns
\end{tabular}




\section{Conclusion}

The purpose of this exploratory research was to provide a better understanding about the role of universities on enterprises' innovation practices in emerging economies. To achieve this objective, in the context of Mexico, we explored the enterprises' motivations to collaborate with universities in terms of innovation purposes (exploration and exploitation) or alternatives to access to public funds (compulsory requirement of being involved in a university partnership).

In this sense, our results evidenced that Mexican innovative enterprises are more likely to collaborate with universities in the development of radical innovations than in the development of incremental innovations (H1), that the role of universities is greater when the enterprises are involved in science-based collaborations than when they are involved in mixed collaborations (H2), that access to government subsidies with compulsory university partnerships is greater when the enterprise is more interested in exploratory practices than in exploitative practices (H3), and that the involvement of universities in government subsidy programs is greater in mixed collaborations than in exclusively science-based collaborations (H4). In this regard, Barge-Gil (2010) have explained this fact by the existence of obstacles in terms of response to the initiatives (universities do not follow the same market times as enterprises because they have more bureaucratic burdens), understanding (universities and enterprises do not speak the same language), and knowledge about the existence of grants (only a limited number of enterprises have access to information about the programs). However, at difference of current studies in emerging economies (Armanios et al. 2016; Bastos et al. 2014; Kruss and Visser 2017; Santarelli and Tran 2016) that continue pay attention on those emerging economies' negative conditions (obstacles, dilemmas and challenges) that limited university-enterprise partnerships, this paper tried to contribute on the debate about the contribution of universities in the radical innovation process of enterprises motivated by a direct enterprises interest for strategic purposes as well as by an indirect enterprises interest of covering the government requirements for accessing to R\&D subsidies. Elements that are part of agendas of research lines such as university technology transfer, quadruple helix perspective (Miller et al. 2016), university-enterprise relationships, open innovation, innovation performance (Gassmann 2006; Greco et al. 2016; Perkmann and Walsh 2007; Van de Vrande et al. 2009) and effectiveness of R\&D subsidies (Dimos and Pugh 2016; García-Quevedo 2004).

This study has several limitations and several unanswered or unexplored questions that are interesting directions for future research. The first limitation is related to the database used. As a result of the INEGI's confidentiality rules, we only had access to the data at its facilities. We did not have access to all the variables and their treatment/analysis was limited by the statistical resources available. Therefore, we used several proxies such the measures adopted to coding university partnerships based on the available data of a sample of mexican enterprises. In this regard, following the ideas from Autio et al. (2014), a natural extension of this paper could be continue exploring our sample with a longitudinal perspective in order to understand the real effect or impact of universities-enterprise relationships on innovation performance as well as spillover effects in their location. This will requires taking into account the implementation of control groups (e.g., comparison across enterprises that have not collaborated with universities as well as not have received subsidies). A real challenge could be doing this analysis across emerging economies. The second limitation was related to the proxies used to test the models, which need to be improved. One example is the analysis of the environmental level. According to Feldman 
(2014), as the agents who recognize opportunities, mobilize resources, and create value, entrepreneurs are the key to the creation of organizations and the building of capacities to sustain regional economic development. Entrepreneurs benefit from their location, but they are also agents of change who can transform their local communities. A natural extension of this paper would be to explore the influence of location, in particular regional differences that may have a significant influence on innovation and entrepreneurial activities. In the line of Guerrero et al. (2016) and Miller et al. (2016), it is still necessary an in-depth analysis about the transmutation of university and enterprises business models into a new configuration of sustained entrepreneurial and innovation ecosystems adopting a social and economic perspective. The third limitation was the proxies used in the analysis of compulsory university-enterprise partnership to access to public innovation incentives. Based on Dimos and Pugh (2016), it is still necessary to continue exploring the effectiveness of R\&D subsidies in stimulating a collaborative behavior instead of opportunistic behavior on university-enterprise R\&D as well as the generation of tangible outcomes.

Even than those limitations, some implications for the main actors involved in the Mexican innovation system emerge from our study. For policymakers, the study presents evidence two motivations and determinants behind innovation practices of enterprisesuniversity partnerships. In other words, this study presents some direct and indirect outputs but is still necessary to consider the valuation of outcomes. If policymakers wish to promote a transition towards a knowledge-based economy, they must reinforce the innovation system as well as the entrepreneurial ecosystem (investment market, educational system, labor market, security and stable regulations for SMEs, among others). For enterprise managers, this study also offers several insights that need to be taking into account in the configuration of innovation practices with different agents (commercial, scientific and mixed). In particular, insights about the develop of radical or incremental innovation strategies. However, these aspects could be used such a reference but at the end each partnership requires time, trust and common objectives. For university managers, the entrepreneurial university model is a good example to follow in their transformation processes.

Acknowledgements Maribel Guerrero acknowledges the financial support from Santander Universidades (Grant Iberoamerica Scholarship for Young Researchers). David Urbano acknowledges the financial support from projects ECO2013-44027-P (Spanish Ministry of Economy \& Competitiveness) and 2014-SGR-1626 (Economy \& Knowledge Department—Catalan Government). Fernando Herrera acknowledges the financial support from the Tecnológico de Monterrey (ITESM) (Grant PhD scholarship).

Open Access This article is distributed under the terms of the Creative Commons Attribution 4.0 International License (http://creativecommons.org/licenses/by/4.0/), which permits unrestricted use, distribution, and reproduction in any medium, provided you give appropriate credit to the original author(s) and the source, provide a link to the Creative Commons license, and indicate if changes were made.

\section{References}

Acs, Z. J., \& Amorós, J. E. (2008). Entrepreneurship and competitiveness dynamics in Latin America. Small Business Economics, 31(3), 305-322.

Acs, Z. J., \& Audretsch, D. B. (1991). R\&D, firm size and innovative activity. Innovation and Technological Change: An International Comparison, 98(2), 451-456.

Alcalde, H., \& Guerrero, M. (2016). Open business models in entrepreneurial stages: Evidence from young Spanish firms during expansionary and recessionary periods. International Entrepreneurship and Management Journal, 12(2), 393-413. 
Almus, M., \& Czarnitzki, D. (2003). The effects of public R\&D subsidies on firms' innovation activities: The case of Eastern Germany. Journal of Business and Economic Statistics, 21(2), 226-236.

Alsos, G. A., Hytti, U., \& Ljunggren, E. (2011). Stakeholder theory approach to technology incubators. International Journal of Entrepreneurial Behaviour and Research, 17, 607-625.

Álvarez, R., \& Crespi, G. A. (2015). Heterogeneous effects of financial constraints on innovation: Evidence from Chile. Science and Public Policy, 42(5), 711-724.

Amit, R., \& Schoemaker, P. J. H. (1993). Strategic assets and organizational rent. Strategic Management Journal, 14(1), 33-46.

Armanios, D. E., Eesley, C. E., Li, J., \& Eisenhardt, K. M. (2016). How entrepreneurs leverage institutional intermediaries in emerging economies to acquire public resources. Strategic Management Journal. doi: $10.1002 / \mathrm{smj} .2575$.

Arora, A., \& Fosfuri, A. (2003). Licensing the market for technology. Journal of Economic Behavior \& Organization, 52(2), 277-295.

Aschhoff, B. (2009). The effect of subsidies on R\&D investment and success-Do subsidy history and size matter? ZEW-Centre for European Economic Research Discussion Paper, (09-032).

Aschhoff, B., \& Sofka, W. (2009). Innovation on demand-Can public procurement drive market success of innovations? Research Policy, 38(8), 1235-1247.

Astrom, T., Eriksson, M. L., Niklasson, L., \& Arnold, E. (2008). International Comparison of Five Institute Systems. Denmark: Forsknings-og Innovationsstyrelsen.

Audretsch, D. (2012). Determinants of High-Growth Entrepreneurship Report prepared for the OECD/DBA International Workshop on High-growth firms: local policies and local determinants, Copenhagen, 28 March 2012.

Audretsch, D. (2014). From the entrepreneurial university to the university for the entrepreneurial society. Journal of Technology Transfer, 39(3), 313-321.

Autio, E., Kenney, M., Mustar, P., Siegel, D., \& Wright, M. (2014). Entrepreneurial innovation: The importance of context. Research Policy, 43(7), 1097-1108.

Barbero, J. L., Casillas, J. C., Wright, M., \& Garcia, A. R. (2014). Do different types of incubators produce different types of innovations? The Journal of Technology Transfer, 39(2), 151-168.

Barge-Gil, A. (2010). Cooperation-based innovators and peripheral cooperators: An empirical analysis of their characteristics and behavior. Technovation, 30(3), 195-206.

Barney, J. B. (1991). Firm resources and sustained competitive advantage. Journal of Management, 17, 99-120.

Bastos, A. P., Serra, M., Almeida, L., \& Diniz, M. J. (2014). University-enterprise partnerships in the Brazilian Amazon: Obstacles, dilemmas and challenges. . Transnational Corporations Review, 6(1), 71-85.

Bayona, C., García-Marco, T., \& Huerta, E. (2001). Firms' motivations for cooperative R\&D: An empirical analysis of Spanish firms. Research Policy, 30, 1289-1307.

Becker, W., \& Dietz, J. (2004). R\&D cooperation and innovation activities of firms-Evidence for the German manufacturing industry. Research Policy, 33(2), 209-223.

Belderbos, R., Carree, M., \& Lokshin, B. (2004). Cooperative R\&D and firm performance. Research Policy, 33(10), 1477-1492.

Bellucci, A., \& Pennacchio, L. (2016). University knowledge and firm innovation: Evidence from European countries. The Journal of Technology Transfer, 41(4), 730-752.

Benavente, J. M., Crespi, G., \& Maffioli, A. (2007). Public support to firm-level innovation: an evaluation of the FONTEC program. Washington, DC: Inter-American Development Bank.

Bonaccorsi, A., Colombo, M. G., Guerini, M., \& Rossi-Lamastra, C. (2013). University specialization and new firm creation across industries. Small Business Economics, 41(4), 837-863.

Boschma, R. (2005). Proximity and innovation: A critical assessment. Regional Studies, 39(1), 61-74.

Boyd, B. K. (1991). Strategic planning and financial performance: A meta-analytic review. Journal of Management Studies, 28(4), 353-374.

Bozeman, B. (2000). Technology transfer and public policy: A review of research and theory. Research Policy, 29(4-5), 627-655.

Brenes, E. R., Camacho, A. R., Ciravegna, L., \& Pichardo, C. A. (2016). Strategy and innovation in emerging economies after the end of the commodity boom-Insights from Latin America. Journal of Business Research. doi:10.1016/j.jbusres.2016.03.059.

Callahan, C. M., Vendrzyk, V. P., \& Butler, M. G. (2012). The impact of implied facilities cost of money subsidies on capital expenditures and the cost of debt in the defense industry. Journal of Accounting and Public Policy, 31(3), 301-319.

Caloghirou, Y., Tsakanikas, A., \& Vonortas, N. S. (2001). University-industry cooperation in the context of the European Framework Programmes. Journal of Technology Transfer, 26(1-2), 153-161. 
Capon, N., Farley, J. U., \& Hoenig, S. (1990). Determinants of financial performance: A meta-analysis. Management Science, 36(10), 1143-1159.

Cárdenas, S., Cabrero, E., \& Arellano, D. (2012). The difficult linkage university-enterprise in Mexico: Towards the construction of the triple helix?. México: CIDE.

Carson, D. J. (1985). The evolution of marketing in small firms. European Journal of Marketing, 19, 7-16.

Cassiman, B., \& Veugelers, R. (2002). R\&D cooperation and spillovers: Some empirical evidence from Belgium. The American Economic Review, 92(4), 1169-1184.

Chesbrough, H. (2003). Open Innovation: The New Imperative for Creating and Profiting from Technology. Boston, MA: Harvard Business School Press.

Chung, J. W., Bae, Z. T., \& Kim, J. S. (2003). Changing patterns of technological cooperation activities of innovative small firms along technological development stages in the Korean telecommunication sector. Technovation, 23(2), 163-173.

Cohen, W. M., \& Klepper, S. (1996). A reprise of size and R\&D. The Economic Journal, 106(437), 925-951.

Cohen, W. M., \& Levinthal, D. A. (1990). Absorptive capacity: A new perspective on learning and innovation. Administrative Science Quarterly, 35(1), 128-152.

Cohen, W. M., Nelson, R. R., \& Walsh, J. P. (2002). Links and impacts: The influence of public research on industrial R\&D. Management Science, 48(1), 1-23.

Colombo, M. G., \& Delmastro, M. (2002). The determinants of organizational change and structural inertia: Technological and organizational factors. Journal of Economics \& Management Strategy, 11(4), 595-635.

Colombo, M. G., Delmastro, M., \& Grilli, L. (2004). Entrepreneurs' human capital and the start-up size of new technology-based firms. International Journal of Industrial Organization, 22(8), 1183-1211.

CONACYT. (2011). Informe General del Estado de la Ciencia y la Tecnología 2010. Mexico: Consejo Nacional de Ciencia y Tecnología.

Crespi, G., \& Zúñiga, P. (2012). Innovation and productivity: Evidence from six Latin American countries. World Development, 40(2), 273-290.

Czarnitzki, D., Ebersberger, B., \& Fier, A. (2007). The relationship between R\&D collaboration, subsidies and R\&D performance: Empirical evidence from Finland and Germany. Journal of Applied Econometrics, 22(7), 1347-1366.

Damanpour, F. (1991). Organizational innovation: A meta-analysis of effects of determinants and moderators. Academy of Management Journal, 34(3), 555-590.

De Fuentes, C., \& Dutrénit, G. (2012). Best channels of academia-industry interaction for long-term benefit. Research Policy, 41(9), 1666-1682.

De Fuentes, C., \& Dutrénit, G. (2016). Geographic proximity and university-industry interaction: The case of Mexico. The Journal of Technology Transfer, 41(2), 329-348.

Diario Oficial. (2014). Consejo Nacional de Ciencia y Tecnología. Estados Unidos Mexicanos: Presidencia de la República. [http://www.fiderh.org.mx/21_ciencia_y_tecnologia.pdf], last access October 2015.

Dimos, C., \& Pugh, G. (2016). The effectiveness of R\&D subsidies: A meta-regression analysis of the evaluation literature. Research Policy, 45(4), 797-815.

Dutrénit, G., De Fuentes, C., \& Torres, A. (2010). Channels of interaction between public research organisations and industry and their benefits: Evidence from Mexico. Science and Public Policy, 37(7), 513-526.

Easterby-Smith, M., Lyles, M. A., \& Peteraf, M. A. (2009). Dynamic capabilities: Current debates and future directions. British Journal of Management, 20(s1), S1-S8.

Eisenhardt, K., \& Martin, J. (2000). Dynamic capabilities: What are they? Strategic Management Journal, 21, 1105-1121.

Feldman, M. P. (2014). The character of innovative places: Entrepreneurial strategy, economic development, and prosperity. Small Business Economics, 43(1), 9-20.

Feller, I. (2005). A historical perspective on government-university partnerships to enhance entrepreneurship and economic development. In S. Shane (Ed.), Economic development through entrepreneurship: Government, university and business linkages. Cheltenham: Edward Elgar.

Fritsch, M., \& Lukas, R. (2001). Who cooperates on R\&D? Research Policy, 30(2), 297-312.

García-Quevedo, J. (2004). Do public subsidies complement business R\&D? A meta-analysis of the econometric evidence.Kyklos, 57(1), 87-102.

Gassmann, O. (2006). Opening up the innovation process: Towards an agenda. R\&D Management, 36(3), 223-228.

Gianiodis, P. T., Markman, G. D., \& Panagopoulos, A. (2016). Entrepreneurial universities and overt opportunism. Small Business Economics, 47(3), 609-631. 
Grant, R. B. (1991). A resource-based theory of competitive advantage: Implications for strategy formulation. California Management Review, 33, 114-135.

Greco, M., Grimaldi, M., \& Cricelli, L. (2016). An analysis of the open innovation effect on firm performance. European Management Journal, 34, 501-516.

Greene, W. (1992). Econometric analysis. New York: Macmillan.

Grimaldi, R., Kenney, M., Siegel, D. S., \& Wright, M. (2011). 30 years after Bayh-Dole: Reassessing academic entrepreneurship. Research Policy, 40(8), 1045-1057.

Gruber, M., \& Henkel, J. (2006). New ventures based on open innovation-An empirical analysis of start-up firms in embedded Linux. International Journal of Technology Management, 33(4), 356-372.

Gruber, M., MacMillan, I. C., \& Thompson, J. D. (2008). Look before your leap: Market opportunity identification in emerging technology firms. Management Science, 54(9), 1652-1665.

Guerrero, M., Cunningham, J. A., \& Urbano, D. (2015). Economic impact of entrepreneurial universities' activities: An exploratory study of the United Kingdom. Research Policy, 44(3), 748-764.

Guerrero, M., \& Urbano, D. (2012). The development of an entrepreneurial university. Journal of Technology Transfer, 37(1), 43-74.

Guerrero, M., \& Urbano, D. (2016). The impact of Triple Helix agents on entrepreneurial innovations' performance: An inside look at enterprises located in an emerging economy. Technological Forecasting and Social Change. doi:10.1016/j.techfore.2016.06.015.

Guerrero, M., Urbano, D., Cunningham, J., \& Organ, D. (2014a). Entrepreneurial universities in two European regions: A case study comparison. The Journal of Technology Transfer, 39(3), 415-434.

Guerrero, M., Urbano, D., Fayolle, A., Klofsten, M., \& Mian, S. (2016). Entrepreneurial universities: Emerging models in the new social and economic landscape. Small Business Economics, 47(3), $551-563$.

Guerrero, M., Urbano, D., \& Gajón, E. (2014b). The internal pathways that condition university entrepreneurship in Latin America: An institutional approach. In Sherry Hoskinson \& Donald Kuratko (Eds.), Innovative pathways for university entrepreneurship in the 21st century (pp. 89-118). Innovation: Advances in the Study of Entrepreneurship.

Hagedoorn, J. (1993). Understing the rationale of strategic technology partnering: Interorganizational modes of cooperation and sectorial differences. Strategic Management Journal, 14(5), 371-385.

Hall, B. H., Link, A. N., \& Scott, J. T. (2001). Barriers inhibiting industry from partnering with universities: Evidence from the advanced technology program. Journal of Technology Transfer, 26(1-2), 87-98.

Hall, B. H., Moncada-Paternò-Castello, P., Montresor, S., \& Vezzani, A. (2016). Financing constraints, R\&D investments and innovative performances: New empirical evidence at the firm level for Europe. Economics of Innovation and New Technology, 25(3), 183-196.

Hannan, M. T., \& Freeman, J. (1984). Structural inertia and organizational change. American Sociological Review, 29, 149-164.

Helfat, C., Finkelstein, S., Mitchell, W., Peteraf, M. A., Singh, H., Teece, D. J., Winter, S. G. (2007). Dynamic capabilities: Understanding strategic change in organizations. Blackwell: Oxford, UK.

Helfat, C. E., \& Peteraf, M. A. (2003). The dynamic resource based view: Capability lifecycles. Strategic Management Journal, 24, 997-1010.

Herrera, F., Guerrero, M., \& Urbano, D. (2016). Interconnectivity between academic organizations and established firms for a strategic and knowledge fostering purpose. In J. Ferreira, L. Dana, \& V. Ratten (Eds.), Knowledge Spillover-based Strategic Entrepreneurship (pp. 207-220). Abingdon: Routledge.

Hewitt-Dundas, N. (2013). The role of proximity in university-business cooperation for innovation. The Journal of Technology Transfer, 38(2), 93-115.

Hoskisson, R. E., Eden, L., Lau, C. M., \& Wright, M. (2000). Strategy in emerging economies. Academy of Management Journal, 43(3), 249-267.

Howells, J., Nedeva, M., \& Georghiou, L. (1998). Industry-academic links in the UK. Manchester PREST, University of Manchester.

Kenney, M., \& Mowery, D. (2014). Public Universities and Regional Development: Insights from the University of California System. Palo Alto, CA: Stanford University Press.

Kim, D. J., \& Kogut, B. (1996). Technological platforms and diversification. Organization Science, 7, 283-301.

Kirby, D. A., Guerrero, M., \& Urbano, D. (2011). Making universities more entrepreneurial: Development of a model. Canadian Journal of Administrative Sciences, 28(3), 302-316.

Kruss, G., \& Visser, M. (2017). Putting university-industry interaction into perspective: A view from inside South African universities. Journal of Technology Transfer. doi:10.1007/s10961-016-9548-6.

Laursen, K., \& Salter, A. (2006). Open for innovation: the role of openness in explaining innovation performance among UK manufacturing firms. Strategic Management Journal, 27(2), 131-150. 
Lichtenthaler, U., \& Ernst, H. (2007). Developing reputation to overcome the imperfections in the markets for knowledge. Research Policy, 36(1), 37-55.

Marzo, M., Pedraja, M., \& Rivera, P. (2008). Un modelo de relaciones empresa-universidad. Revista Europea de Dirección y Economía de la Empresa, 17(1), 39-56.

McAdam, M., \& McAdam, R. (2008). High tech start-ups in University Science Park incubators: The relationship between the start-up's lifecycle progression and use of the incubator's resources. Technovation, 28(5), 277-290.

McGrath, R. G., MacMillan, I. C., \& Venkataraman, S. (1995). Defining and developing competence: A strategic process paradigm. Strategic Management Journal, 16(4), 251-275.

Miller, K., McAdam, M., \& McAdam, R. (2014). The changing university business model: A stakeholder perspective. R\&D Management, 44(3), 265-287.

Miller, K., McAdam, R., \& McAdam, M. (2016). A systematic literature review of university technology transfer from a quadruple helix perspective: Toward a research agenda. $R \& D$ Management. doi:10. $1111 /$ radm. 12228 .

Miller, D., \& Shamsie, J. (1996). The resource-based view of the firm in two environments: The Hollywood film studios from 1936 to 1965. Academy of Management Journal, 39, 519-543.

Nambisan, S., Bacon, J., \& Throckmorton, J. (2012). The role of the innovation capitalist in open innovation: a case study and key lessons learned. Research-Technology Management, May-June 2012, 49-57.

Nanda, R., \& Rhodes-Kropf, M. (2013). Investment cycles and startup innovation. Journal of Financial Economics, 110(2), 403-418.

Narayanan, V. K., Colwell, K., \& Douglas, F. L. (2009). Building organizational and scientific platforms in the pharmaceutical industry: A process perspective on the development of dynamic capabilities. British Journal of Management, 20(s1), S25-S40.

Nieto, M. J., \& Santamaria, L. (2007). The importance of diverse collaborative networks for the novelty of product innovation. Technovation, 27(6), 367-377.

O'Shea, R., Allen, T. J., Chevalier, A., \& Roche, F. (2005). Entrepreneurial orientation, technology transfer and spin-off performance of US universities. Research Policy, 34, 994-1009.

O'Shea, R. P., Allen, T. J., Morse, K. P., O'Gorman, C., \& Roche, F. (2007). Delineating the anatomy of an entrepreneurial university: The Massachusetts Institute of Technology experience. $R \& D$ Management, $37(1), 1-16$.

O’Connor, G. C., \& De Martino, R. (2006). Organizing for radical innovation: an exploratory study of the structural aspects of RI management systems in large established firms. Journal of Product Innovation Management, 23(6), 475-497.

OECD. (2005). The measurement of scientific and technological activities. Oslo Manual: Guidelines for Collecting and Interpreting Innovation Data. Paris: OECD.

OECD. (2007). Eurostat-OECD Manual on Business Demography Statistics. Paris: OECD.

OECD. (2010). High-Growth Enterprises: What Governments Can Do to Make a Difference. Paris: OECD.

OECD. (2013). OECD science, technology and industry scoreboard 2013, Accessed: 22-05-2015 _www. oecd-ilibrary.org/docserver/download/9213051e.pdf_.

Olazarán, M., Albizu, E., \& Otero, B. (2009). Technology transfer between technology centres and SMEs: evidence from the Basque Country. European Planning Studies, 17(3), 345-363.

Parker, S. C. (2009). The economics of entrepreneurship. Cambridge University Press.

Penrose, E. (1959). The Theory of the Growth of the Firm. New York: Oxford University Press.

Perkmann, M., Tartari, V., McKelvey, M., Autio, E., Broström, A., D’Este, P., et al. (2013). Academic engagement and commercialisation: A review of the literature on university-industry relations. $R e$ search Policy, 42, 423-442.

Perkmann, M., \& Walsh, K. (2007). University-industry relationships and open innovation: Towards a research agenda. International Journal of Management Reviews, 9(4), 259-280.

Porter, M. E. (1979). How competitive forces shape strategy. Harvard Business Review, 57(2), 5-8.

Porter, M. E. (1980). Competitive Strategy. New York, NY: The Free Press.

Quintini, G., \& Martin, S. (2014) Same Same but Different: School-to-work Transitions in Emerging and Advanced Economies, OECD Social, Employment and Migration Working Papers, No. 154, OECD Publishing, Paris. doi:10.1787/5jzbb2t1rcwc-en.

Ritala, P., \& Hurmelinna-Laukkanen, P. (2013). Incremental and radical innovation in coopetition-The role of absorptive capacity and appropriability. Journal of Product Innovation Management, 30(1), 154-169.

Romanelli, E. (1989). Environments and strategies of organization start-up: Effects on early survival. Administrative Science Quarterly, 34, 369-387. 
Rosenbusch, N., Brinckmann, J., \& Bausch, A. (2011). Is innovation always beneficial? A meta-analysis of the relationship between innovation and performance in SMEs. Journal of Business Venturing, 26(4), 441-457.

Rosenkopf, L., \& Nerkar, A. (2001). Beyond local search: Boundary-spanning, exploration, and impact in the optical disk industry. Strategic Management Journal, 22(4), 287-306.

Rothaermel, F. T., Agung, S. D., \& Jiang, L. (2007). University entrepreneurship: Taxonomy of the literature. Industrial and Corporate Change, 16(4), 691-791.

Rothwell, R., \& Dodgson, M. (1991). External linkages and innovation in small and medium-sized enterprises. $R \& D$ Management, 21(2), 125-137.

Santarelli, E., \& Tran, H. T. (2016). Young innovative companies: Are they high performers in transition economies? Evidence for Vietnam. The Journal of Technology Transfer. doi:10.1007/s10961-0169475-6.

Santiago, F., De Fuentes, C., Dutrénit, G., \& Gras, N. (2016). What hinders innovation performance of services and manufacturing firms in Mexico? Economics of Innovation and New Technology. doi:10. 1080/10438599.2016.1181297.

Scuotto, V., Del Giudice, M., \& Carayannis, E. G. (2016). The effect of social networking sites and absorptive capacity on SMES'innovation performance. The Journal of Technology Transfer. doi:10. 1007/s10961-016-9517-0.

Segarra-Blasco, A., \& Arauzo-Carod, J. M. (2008). Sources of innovation and industry-university interaction: Evidence from Spanish firms. Research Policy, 37(8), 1283-1295.

Shane, S. (2003). Academic entrepreneurship: University spinoffs and wealth creation. USA: Edward Elgar Publishing.

Sissoko, A. (2011). R\&D subsidies and firm-level productivity: evidence from France. IRES Discussion Papers.

Souto-Otero, Manuel, \& Whitworth, Adam. (2016). Adult participation in higher education and the 'knowledge economy': A cross-national analysis of patterns of delayed participation in higher education across 15 European countries. British Journal of Sociology of Education. doi:10.1080/ 01425692.2016.1158639.

Teece, D. J. (2007). Explicating dynamic capabilities: The nature and microfoundations of (sustainable) enterprise performance. Strategic Management Journal, 28(13), 1319-1350.

Teece, D. J., Pisano, G., \& Shuen, A. A. (1997). Dynamic capabilities and strategic management. Strategic Management Journal, 18, 504-534.

Tether, B. S. (2002). Who co-operates for innovation, and why: An empirical analysis. Research Policy, 31(6), 947-967.

Tsai, K. H., \& Wang, J. C. (2009). External technology sourcing and innovation performance in LMT sectors: An analysis based on the Taiwanese technological innovation survey. Research Policy, 38(3), $518-526$.

Urbano, D., \& Guerrero, M. (2013). Entrepreneurial universities socioeconomic impacts of academic entrepreneurship in a European region. Economic Development Quarterly, 27(1), 40-55.

Van de Vrande, V., De Jong, J. P., Vanhaverbeke, W., \& De Rochemont, M. (2009). Open innovation in SMEs: Trends, motives and management challenges. Technovation, 29(6), 423-437.

Van Dijk, C., \& Van den Ende, J. (2002). Suggestion systems: Transferring employee creativity into practicable ideas. $R \& D$ Management, 32, 387-395.

Wernerfelt, B. (1984). A resource-based view of the firm. Strategic Management Journal, 5(2), 171-180.

World Economic Forum. (2013). Entrepreneurial Ecosystems Around the Globe and Company Growth Dynamics. Report Summary for the Annual Meeting of the New Champions 2013. World Economic Forum. http://www3.weforum.org/docs/WEF_EntrepreneurialEcosystems_Report_2013.pdf. Accessed 10 Jan 2016.

World Economic Forum. (2014). Global Competitveness Report 2012-2013. Schwab, K.-Full Data Edition. World Economic Forum. http://www3.weforum.org/docs/WEF_GlobalCompetitivenessReport_ 2012-13.pdf. Accessed 10 Jan 2016.

Wright, M., Clarysse, B., Mustar, P., \& Lockett, A. (2007). Academic entrepreneurship in Europe. Massachusetts: Edward Elgar Publishing.

Wright, M., Filatotchev, I., Hoskisson, R. E., \& Peng, M. W. (2005). Strategy research in emerging economies: Challenging the conventional wisdom. Journal of Management Studies, 42(1), 1-33.

Yamin, M., \& Otto, J. (2004). Patterns of knowledge flows and MNE innovative performance. Journal of International Management, 10(2), 239-258.

Zollo, M., \& Winter, S. G. (2002). Deliberate learning and the evolution of dynamic capabilities. Organization Science, 13(3), 339-351. 